\title{
Leukocytes in Mammary Development and Cancer
}

\author{
Lisa M. Coussens ${ }^{1}$ and Jeffrey W. Pollard ${ }^{2}$ \\ ${ }^{1}$ Department of Pathology and Helen Diller Family Comprehensive Cancer Center, University of California, \\ San Francisco, San Francisco, California 94143 \\ ${ }^{2}$ Department of Developmental and Molecular Biology, Department of Obstetrics and Gynecology and \\ Women's Health, Center for the Study of Reproductive Biology and Women's Health, Albert Einstein \\ College of Medicine, New York, New York 10461 \\ Correspondence: jeffrey.pollard@einstein.yu.edu
}

Leukocytes, of both the innate and adaptive lineages, are normal cellular components of all tissues. These important cells not only are critical for regulating normal tissue homeostasis, but also are significant paracrine regulators of all physiologic and pathologic tissue repair processes. This article summarizes recent insights regarding the trophic roles of leukocytes at each stage of mammary gland development and during cancer development, with a focus on Murids and humans.

\begin{abstract}
M ammary gland development can be divided into discrete phases. An initial analge is laid down from the milk-line during embryonic development resulting in a minimal ductal structure emanating from the nipple. Development of this anlage into a ductal tree is reactivated postnatally by exposure to the female sex steroid hormone estradiol-17 $\beta$ (E2), whose synthesis begins upon entry into puberty. In mice, this occurs at about 3 wk of age and is characterized by the formation of terminal end buds (TEB) at the ends of the ducts. These TEBs are clublike multilaminate epithelial structures that are the proliferative engines that drive mammary development. These structures also contain the mammary stem cells whose progeny differentiate into luminal and myoepithelial cells. The TEB structures disappear on their
\end{abstract}

encounter with the edge of the fat pad and turn into terminal end-ducts (TED) that cease proliferation and which are bilaminar. As the primary branches grow out through the fat pad, secondary branches form to generate the mature tree that in mice is completed about 8 wk of age coincident with sexual maturity. At each estrus cycle thereafter, there is further development of the secondary branches and dependent on mouse strain, a degree of lobuloalveolar development. The next major phase of growth is during pregnancy in response to progesterone and prolactin when there is significant secondary branching morphogenesis, and the generation of the milk producing lobuloalveolar structures sprouting from these branches. At the end of the process, the gland is filled with ducts and alveolar structures with

Editors: Mina J. Bissell, Kornelia Polyak, and Jeffrey Rosen

Additional Perspectives on The Mammary Gland as an Experimental Model available at www.cshperspectives.org

Copyright (C) 2011 Cold Spring Harbor Laboratory Press; all rights reserved; doi: 10.1101/cshperspect.a003285

Cite this article as Cold Spring Harb Perspect Biol 2011;3:a003285 
a commensurate loss of adipocytes. After birth and on suckling, lactation occurs with its effect on the secretory structure of alveoli that flatten to surround a milk-filled lumen. Weaning terminates the lactational process and the gland involutes to re-form a virgin-like structure to begin the cycle again during the next pregnancy (Daniel and Silberstein 1987; Richert et al. 2000; Neville et al. 2002). Every stage of mammary epithelial development is accompanied by changes in the surrounding stroma. This stroma is populated by many immune cells particularly those of the innate system. Although these cells undoubtedly have a role in immunological responses especially during lactation (Paape et al. 2002; Atabai et al. 2007), this review will concentrate on the trophic roles of these hematopoietic cells at each stage of development and during cancer development, with a focus on Murids and humans.

\section{PUBERTAL MAMMARY DEVELOPMENT}

In early postnatal development, classical experiments revealed that instructive signals arise from stromal cells that define the identity of the mammary epithelial structures (Sakakura 1987). In mice, the rudimentary mammary ductal tree begins to develop with the formation of the multilaminate club-shaped TEBs at their distal end. These TEBs grow out through the fatty stroma, bifurcating to generate the primary ductal tree (Richert et al. 2000).

The stroma of the developing mammary gland is dominated by adipocytes (Neville et al. 1998). However, although these cells are required for mammary epithelial development, they do not appear to define its identity (Landskroner-Eiger et al. 2010). Instead adipocytes provide structural support and their secreted adipokines that influence ductal development. Macrophages are found abundantly adjacent to the nipple area and rudimentary ductal structures at $2 \mathrm{wk}$ of age before mammary development commences (Gouon-Evans et al. 2000). Co-incident with the initiation of development the newly formed TEBs is surrounded by a complex stroma containing fibroblasts, macrophages, mast cells, and eosinophils
(Gouon-Evans et al. 2000, 2002; Lilla and Werb 2010) (Figs. 1-4). In contrast, neither basophils nor T and B cells can be detected in the vicinity of the TEBs (Gouon-Evans et al. 2002).

The macrophages have a tendency to accumulate around the shaft of the club and in this vicinity they move rapidly along the sheaf of collagen fibrils that align along the axis of the TEB (Ingman et al. 2006) (Fig. 3). Eosinophils are preferentially located around the head of the TEB and they also concentrate in the cleft that forms as the TEBs bifurcate (Gouon-Evans et al. 2000) (Figs. 1, 4). Mast cells are found in a scattered pattern at the invasive front of the TEBs (Atabai et al. 2007; Lilla and Werb 2010) (Fig. 2). Macrophages and eosinophils persist in these locations through development but disappear as soon as the TEBs turn into TEDs (Gouon-Evans et al. 2000; Lilla and Werb 2010). Thereafter, eosinophils, macrophages and mast cells are not present in significant numbers adjacent to the epithelia until development is restarted during pregnancy (Pollard and Hennighausen 1994; Szewczyk et al. 2000; GouonEvans et al. 2002; Lilla and Werb 2010). However, macrophages are found throughout the adipose tissue during this and other stages of mammary development (Gouon-Evans et al. 2000; Schwertfeger et al. 2006a).

The mechanisms whereby these innate immune cells are recruited to the mammary epithelial structures have not been fully elucidated, although the process is clearly triggered by estrogen. Genetic depletion of the chemoattractant eotaxin completely eliminates the recruitment of eosinophils to the mammary gland even though circulating numbers in bone marrow and peripheral blood are normal (Gouon-Evans et al. 2000). Eotaxin is induced in the mammary gland at puberty coincident with eosinophil recruitment strongly suggesting that this is the estrogen-regulated chemoattractant (Gouon-Evans et al. 2000). Studies of mice in which colony stimulating factor-1 (CSF-1) is depleted owing to homozygosity for the Csf 1 null mutation, osteopetrotic, $\left(C s f 1^{o p}\right)$ have shown that many tissues but not all are severely depleted of macrophages. The mammary gland is one of these severely affected tissues indicating 

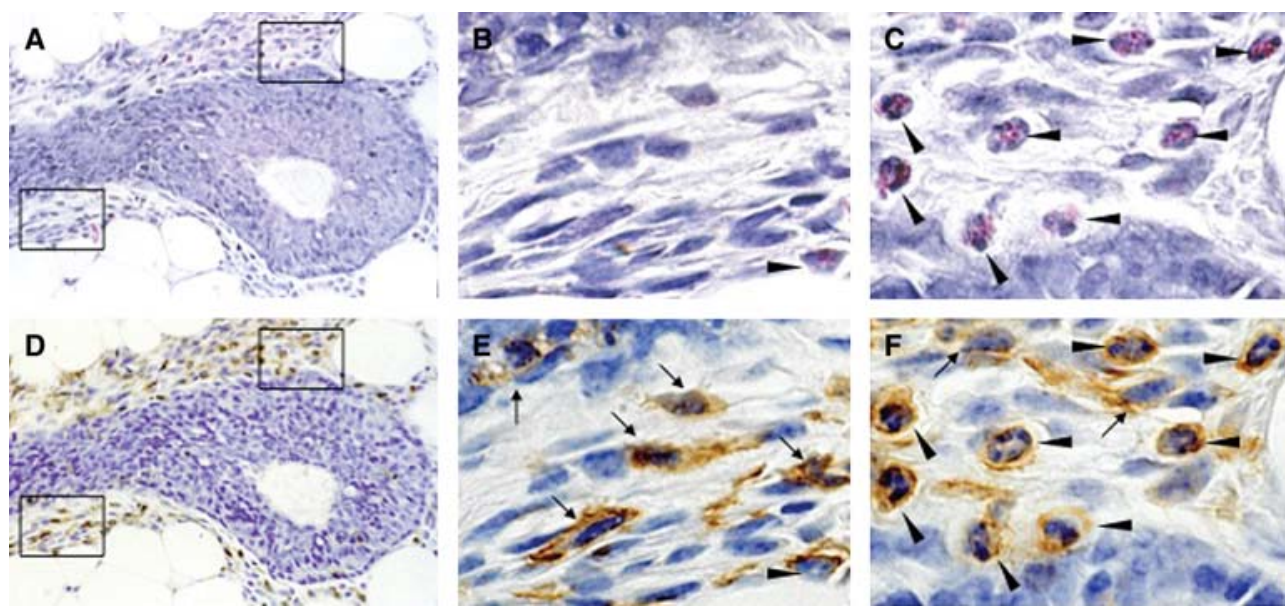

Figure 1. Macrophage and eosinophil recruitment to the terminal end buds of mice. H\&E longitudinal sections of terminal end buds at 5 wk of age. Sections were first stained with $\mathrm{H} \& \mathrm{E}(A-C)$ and then destained and immunostained using anti-F4/80 antibody followed by a peroxidase detection system for positive signal (brown; $D, E, F$ ). Note the presence of a dense stroma particularly around the shaft and beginning of the TEB head that consists of fibroblasts and abundant immune cells. This stroma isolates the epithelial compartment from the adipoctyes of the fat pad but is sparser at the growing tip. $B, C$, and $E, F$ are high-powered views of $A$ and $D$, respectively, and the lower panels boxed in $A$ and $D$ are shown in $B$ and $E$ whereas the upper panels are in $C$ and $F$. The immunostain indicates the $\mathrm{F} 4 / 80$ positive macrophages (arrows) and eosinophils (filled arrow heads) the latter recognized by their eosinophilic granules and polymorphonuclear structures in $C$. Note the distinct but overlapping localization of macrophages and eosinophils around the bulbous head and shaft of the TEB. (Figure adapted from Gouon-Evans et al. [2000] and reprinted here with permission from The Company of Biologists (C) 2000.)

an essential requirement for CSF-1 (Pollard and Stanley 1996; Gouon-Evans et al. 2000). However, although CSF-1 is expressed by the mammary epithelium (Ryan et al., 2001), transplantation experiments indicate that this epithelial expression is not required for macrophage recruitment during development (Van Nguyen and Pollard, 2002). This suggests that another epithelial-derived chemoattractant recruits the macrophages to the TEB and that
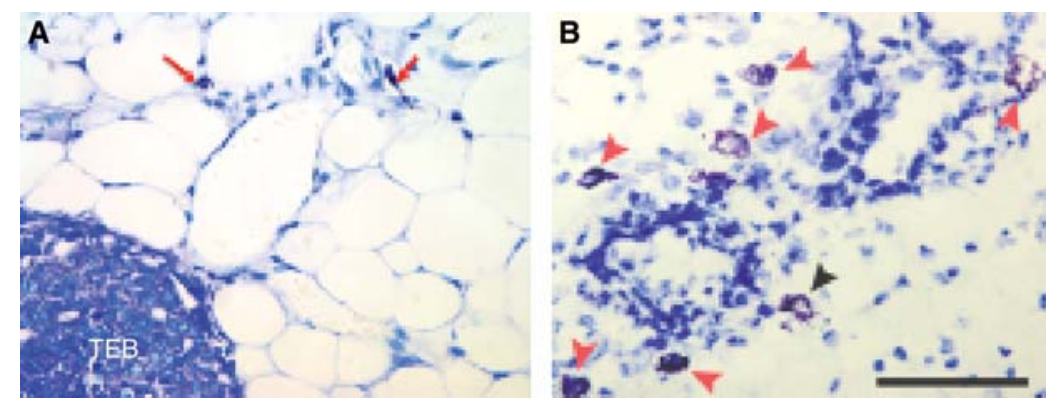

Figure 2. Distribution of mast cells around the terminal end bud of mice. Shown are formalin fixed, paraffin embedded sections stained with toluidine blue in which mast cells are identified by an enzymatic reaction to detect chymase a defining enzyme of these cells. $(A)$ Mast cells (red arrows) shown in the fatty stroma in front of an invading terminal end bud (TEB]. (B) Many mast cells (red arrows) adjacent to developing mammary epithelium of mice at $5 \mathrm{wk}$ of age. Black arrow shows a mast cell degranulating. (Panel $A$ reprinted from Lilla and Werb [2010] and reprinted here with permission from Elsevier (C) 2010; panel B kindly provided by Dr. Zena Werb, USCF). Bar $50 \mu \mathrm{m}$. 
L.M. Coussens and J.W. Pollard
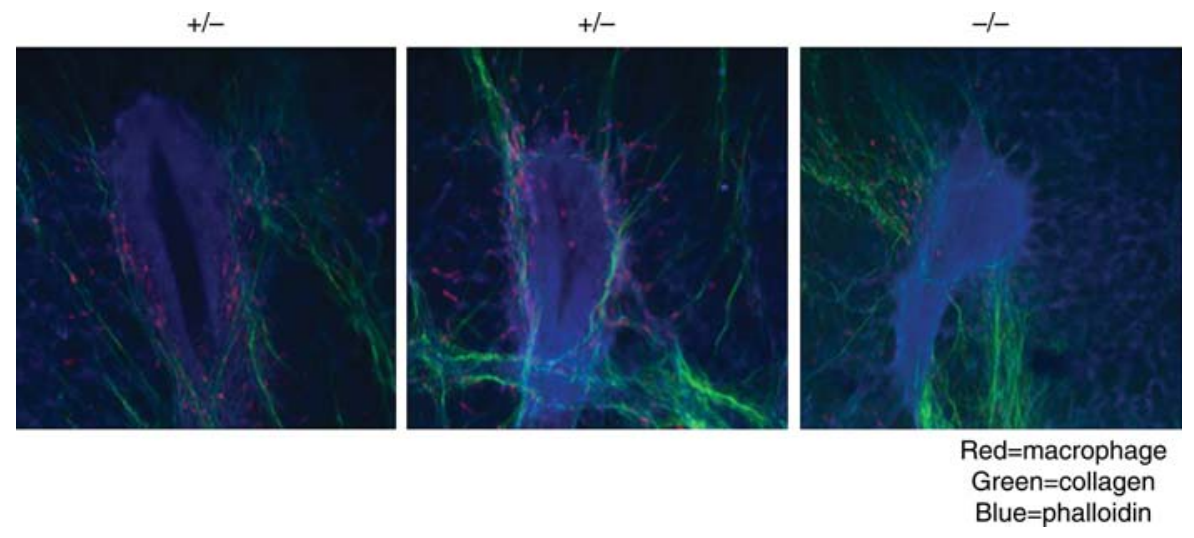

Figure 3. Association of macrophages and collagen fibers with the terminal end bud. Multiphoton imaging of frozen sections of terminal end buds with nuclei stained with DAPI in which the collagen fibers are shown by second harmonic residence and pseudo-colored in green while macrophages are shown by expression of GFP from the Cs1r-promoter (data from Sasmono et al. 2003) pseudocolored to red. In $A$ and $B$, TEBs from mice heterozygous $\left({ }^{+-}\right)$for the $C s f 1^{\text {op }}$ allele, whereas $C$ is from mice homozygous $\left({ }^{-/}\right)$for this allele. Note the sheafing of the TEB with collagen 1 containing fibers and the association of macrophages with these fibers. The tubular structure with the visible collagen sheaf running laterally across the image in $B$ is a blood vessel. In $C$, the collagen fibers are more disorganized and the TEB is rounder in structure (data from Ingman et al. 2006).

CSF-1 is necessary for their lineage development systemically and for their development from monocytes within the tissue. Interestingly, eosinophils situated at the TEB specifically express the monocyte chemoattractant, CCL-6 (C10), suggesting a cross-talk between these eosinophils and macrophages (Gouon-Evans et al. 2002). However, it is unknown whether CCL-6 is required for macrophage recruitment at this site.

Human mammary development is much less well understood and appears to be less defined as its processes are rather sporadic (Howard and Gusterson 2000). Sexual dimorphism in contrast to the embryonic specification in mice, in humans is initiated by sex hormone secretion at puberty. In females proliferative end budlike structures form and ductal outgrowth occurs that results in the formation of terminal ductal lobular units. According to the individual, variable and extensive branching occurs through puberty that ultimately leads to a structure where primary ducts lead from the nipple to a complex branching pattern of subsidiary ducts that in turn lead to segmental ducts and smaller subsegmental ducts. These subsegmental ducts in turn lead to terminal ducts that lead to blind ended acini. The collection of acini embedded in a complex stroma is referred to as the terminal duct lobular alveolar unit (TDLU). This is thought to be the functional unit of the breast and also thought to be the site of tumor initiation. Strikingly there is great variation in proliferation rates in different TDLUs suggesting the predominance of local factors (Howard and Gusterson 2000). Little is known about hematopoietic cells in human mammary gland during development. Extramedullary hematopoiesis has been described adjacent to the ductal structures in infant breasts until four months of age (Anbazhagan et al. 1991). Macrophages are abundant cells in nipple aspirates from reproductive age women (King et al. 2002). Intriguingly macrophages in the human breast express aromatase suggesting that they may be a local source of estradiol (Mor et al. 1998). A variation in macrophage density therefore could possible explain localized differences in growth of the TDLUs.

Mechanistic studies performed in mice strongly argue for important roles for hematopoietic cells in mammary ductal development. Postnatal ablation of bone marrow cells 


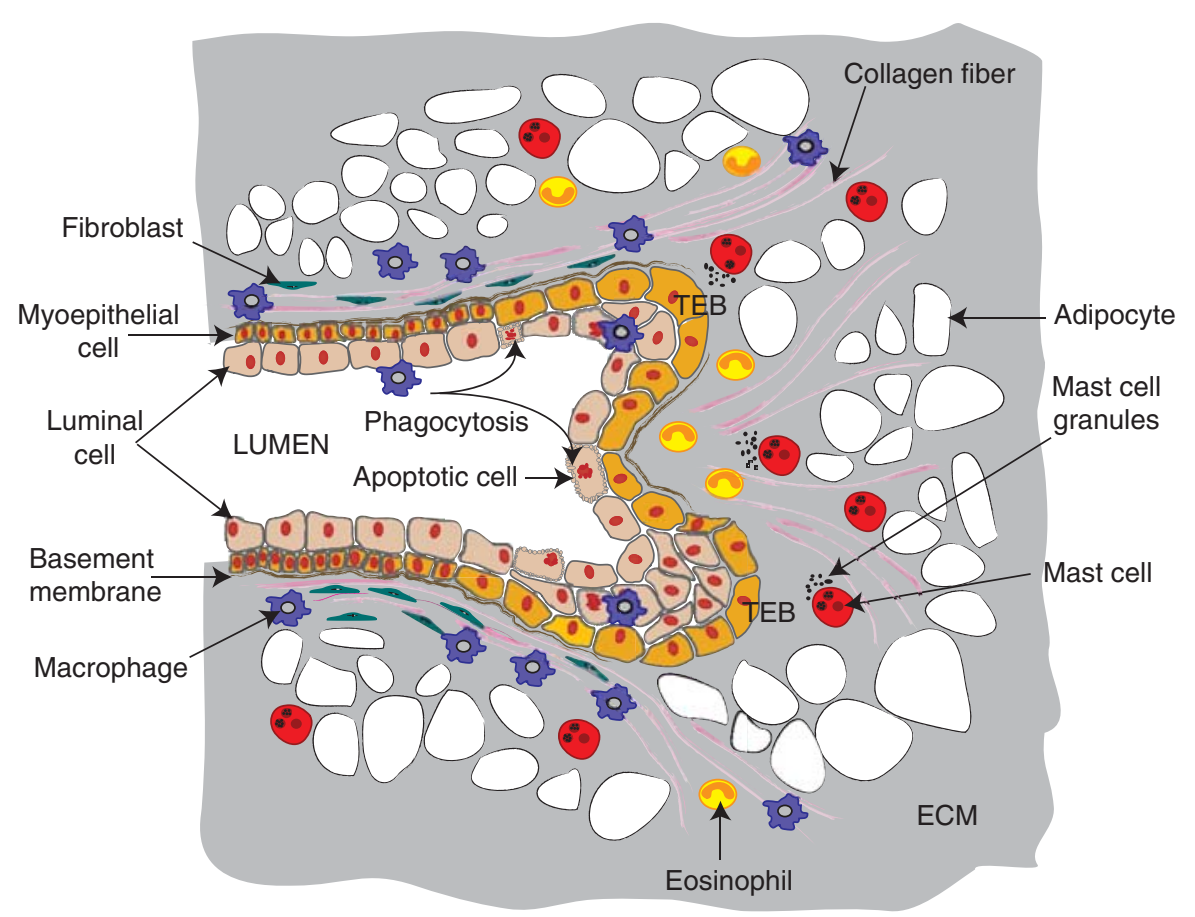

Figure 4. Topography of immune cells in the developing terminal end bud. The diagram shows a schematic of a terminal end bud (TEB) that is bifurcating to give two ductal branches. This TEB is surrounded by a dense fibroblastic stoma and encased by a fibrillar collagen network that is aligned in the direction of the outgrowth through the mammary fat pad that is densely populated by adipocytes. Abundant numbers of innate immune cells are recruited to the TEB and have preferred domains as indicated. Macrophages are enriched around the base and shaft of the TEB but move rapidly up and down the collagen fibers. In addition, they are found in the TEB itself where they phagocytose the apoptotic epithelial cells in the process of lumen formation. Mast cells in contrast, are preferentially located in the stroma in front of the invading TEBs where they provide proteases that enhance TEB invasion. Eosinophils in turn, are found around the bulbous head of the TEB and also are found in the cleft of the bifurcating TEB. Genetic ablation of each of these cell types as described in the text indicates roles for them in the branching morphogenesis of the mammary gland and their combined functions results in a fully branched ducal tree that forms during puberty.

by irradiation before mammary development begins, blocks subsequent mammary development. This developmental block can be overridden by restoration of the bone marrow by transplantation of the irradiated mice, a treatment that results in a complete rescue of the mammary tree. This indicates that irradiation does not irrevocably damage mammary stem cells (Gouon-Evans et al. 2000). In the few mice that survive irradiation without transplantation but who are severely depleted of leukocytes, the mammary gland also fails to develop to any significant extent (Gouon-Evans et al. 2000).

Mice homozygous for the Csfi null mutation, osteopetrotic, $\left(C s f 1^{o p}\right)$ have inhibited mammary development characterized by fewer numbers of TEBs, reduced branching, and diminished ductal length compared to wild-type mice. Thus in these macrophage-deficient mice, although a ductal tree eventually develops that fills the fat pad, the resulting gland is atrophic (Gouon-Evans et al. 2000). A similar defect was found in the CSF-1 receptor null mutant mice (Dai et al. 2002). The continuous requirement for macrophages in mammary development was shown by transgenic add-back experiments where CSF-1 was expressed exclusively in the mammary epithelium on a tetracycline-regulated system without rescue of any systemic phenotypes. In these transgenic 
mice ductal development was rescued in the homozygous $C s f 1^{o p}$ null mice coincident with macrophage recruitment, but only for the duration of the CSF-1 expression (Van Nguyen and Pollard 2002). These data together with expression data showing that the CSF-1 receptor is only expressed in macrophages in the mammary gland, indicates an important role for macrophages in mammary ductal development throughout puberty (Gouon-Evans et al. 2000). This conclusion was reinforced by studies that showed macrophage depletion using a conditional suicide gene approach inhibited mammary epithelial cell proliferation in a model of fibroblast growth factor (FGF) receptorinduced epithelial hyperplasia (Schwertfeger et al. 2006b).

The mammary ductal epithelium can be seeded from a single bipotential stem cell (Shackleton et al. 2006). These stem cells can form an entire mammary epithelial tree on transplantation into a recipient mammary fat pad. The efficiency of this process is dramatically reduced in mice depleted for macrophages either by homozygosity of the CSF-1 null mutation or chemically, using the macrophage-specific liposome-encapsulated clodronate (Gyorki et al. 2009). Thus, macrophages potentiate the stem cell niche that enables engraftment and growth of the stem cells. This data is consistent with effects of macrophage depletion on mammary ductal development because this development is driven by proliferation and differentiation of the stem cells that lie in the TEBs.

Depletion of eosinophils using mice homozygous for a null mutation in the gene encoding the eosinophil chemoattractant, eotaxin, resulted in a decreased numbers of TEBs, and reduced branching although ductal lengths were normal (Gouon-Evans et al. 2000). In contrast, depletion of interleukin (IL)-5, another chemoattractant for eosinophils, did not affect mammary development (Gouon-Evans et al. 2002). However, overrecruitment of eosinophils by transgenic IL- 5 expression throughout the mammary gland inhibited TEB formation and ductal branching compared to wild-type mice. This in part, was because of an inhibition of epithelial cell proliferation (Sferruzzi-Perri et al. 2003). The unique position of eosinophils in the normal mammary gland and the preferential effect of their depletion on ductal branching strongly suggest that their role is in regulating branching complexity perhaps by providing inhibitory signals at branch point (Gouon-Evans et al. 2000).

Mast cell depletion in mice carrying a mutation in the $\mathrm{W}$ locus $\left(W^{\text {ash }}\right)$ that encodes the c-kit receptor required for the formation of these cells results in a reduced number of TEBs and branches as well as defective TEB outgrowth caused by a reduction of epithelial cell proliferation (Lilla and Werb 2010). These data indicate that hematopoietic cells of the innate immune system play an important role in the branching morphogenesis of the mammary gland. The precise location of the different types of cells suggests they have an important role in patterning as over-abundance can also lead to inhibited development. Indeed the migratory nature of these cells makes them perfectly equipped for precisely delivering growth factors or growth inhibitors as well as proteases in a temporal and spatial manner. However, the mechanisms whereby these innate immune cells potentiate mammary development are largely unknown.

TEB proliferation is accompanied by apoptosis so that the multilaminate epithelium is remodeled to give a duct consisting of a single layer of columnar epithelium overlaying a single layer of myoepithelial cells. Failure of this ductal clearance inhibits proper mammary development (Humphreys 1999). Macrophages are found in the TEBs engulfing apoptotic cells and in their absence, this process may be inefficient (Humphreys et al. 1996; Gouon-Evans et al. 2000). However, even in macrophagedeficient mice, the ductal structure is reduced to a single columnar layer (Gouon-Evans et al. 2000) and thus there are likely to be compensatory mechanisms through the action of nonprofessional phagocytes as is found for development of other organs (Dai et al. 2002).

TEBs are surrounded by a collagenous matrix (Hinck and Silberstein 2005; Schwertfeger et al. 2006b) and these structures grow 
out through a funnel of organized fibers that are composed primarily of fibrillar collagen type 1 (Ingman et al. 2006). Intravital imaging of TEBs using multiphoton microscopy of mice expressing green fluorescent protein (GFP) regulated by a Csf1r-promoter (Sasmono et al. 2003) show that macrophages travel up and down these fibers at a fast rate and also "jump" between them (Ingman et al. 2006). Macrophage depletion using Csf1 $1^{o p / o p}$ mice results in a reduced number of these complex fibers compared to wild-type mice but without any effect on collagen 1 synthesis that is from the fibroblasts and epithelial cells. Furthermore the fibers that remain in the macrophage-depleted mice are also less orientated than the fibers in wild-type mammary glands (Ingman et al. 2006). Multiphoton imaging shows that in the absence of macrophages, the orientation of TEB outgrowth is perturbed with a failure to form the smooth fanlike pattern at the ductal front as observed in normal mice. In addition, macrophage deficiency results in TEBs that are rounder and more distorted than those in wild-type mice (Fig. 3). Correction of the macrophage defect by transgenic expression of CSF-1 in the mammary epithelium resulted in restoration of collagen bundling and a correction of the distortion of the TEBs. These data suggest a primary role for macrophages in bundling of these large collagen fibers and that these fibers in turn are required for the guiding the morphogenesis of the TEBS to generate a properly spaced ductal structure (Ingman et al. 2006). The mechanism for this action on collagen bundling is unknown but macrophages synthesize many proteases including matrix metalloprotease (MMP)-7 an enzyme that remodels collagen that might be necessary for the processing of the extracellular matrix (ECM) and in particular, the collagenous structures. Macrophages may also significantly affect other matrix molecules through expression of different proteases as well as molecules involved in matrix remodeling such as Lysyl oxidase and SPARC (Sangaletti et al. 2008). For example, macrophages are rich sources of MMP9 that is involved in ECM remodeling (Djonov et al. 2001; Egeblad and Werb 2002).
Mast cell degranulation is required for ductal outgrowth indicating a requirement for granule products. These products consist of proteases and growth factors. Indeed, depletion of serine proteases with a mutation in the di-peptidyl peptidase 1 (DPPI; cathepsin C) gene that activates many serine proteases results in inhibited mammary ductal development that includes a reduction in the numbers of TEBs and an inhibition in terminal duct formation (Lilla and Werb 2010). Cathepsin C degrades collagens 1 and IV and this protease is synthesized by macrophages as well as mast cells (Gocheva et al. 2010; Lilla and Werb 2010). Thus, cathepsin C alterations of the ECM might also be part of the mechanism behind the effects of depletion of these two cell types on ductal development. However, cell type-specific ablation studies have not been performed to definitively assign these functions to mast cells or macrophages.

\section{PREGNANCY AND LACTATION}

Ductal development is re-initiated on pregnancy under the influence of many systemic and local factors including the hormones progesterone and prolactin. Around mid-pregnancy in mice, there is a dramatic growth of lobuloalveolar structures that decorate these newly expanded branches with the mammary fat pad expanding to accommodate the outgrowths. At the end of pregnancy the adipocytes have largely been replaced by the lobuloalveolar structures and a milk-producing gland is fully formed that is 7-10-times heavier than the virgin gland (Atabai et al. 2007). After parturition with its associated loss of progesterone and on pup suckling, a lactational switch is effected and the alveoli secrete milk and appear as flattened cells surrounding large milk-filled lumens (Neville et al. 2002). There are relatively few studies of the pregnant human breast but it appears as in rodents that there is an expansion of lobular-alveolar structures with commensurate loss of adipocytes. The lactating gland has alveoli full of milk that is followed by involution postweaning with the alveolar cells dying of apoptosis (Howard and Gusterson 2000). 
Mast cells are found adjacent to the expanding alveolar structures and their density increases according to lobuloalveolar development, but their density significantly declines on the lactational switch (Szewczyk et al. 2000). Macrophages also accumulate during pregnancy and they are found in close apposition to and aligned alongside the epithelial structures (Gouon-Evans et al. 2002). Although these somewhat diminish in numbers during lactation, macrophages are found stretched along the outside of the alveolar walls (Gouon-Evans et al. 2002). Both macrophages and neutrophils are found abundantly in milk of farm species and humans where they are thought to have an antimicrobial role. In addition, B cells are found in milk and this is in turn a rich source of antibodies (Atabai et al. 2007). These innate and acquired immune cells are recruited and undergo a transepithelial migration into the alveolar lumens although the mechanisms behind this biology are poorly understood. Nevertheless, it is clear that the lactating mammary gland is an extension of the mucosal immune system such that the milk confers immune protection to the suckling neonate (Brandtzaeg 2010).

Transcriptome analysis of progesterone responsive genes in mammary organoid cultures has also shown up-regulation of many inflammatory molecules several of which are chemoattractants for innate immune cells including serum amyloid proteins A1, 2, and 3 (Saa1-3), suggesting that these molecules may be involved in leukocyte recruitment (Santos et al. 2009). In progesterone treated mice undergoing alveolar development, there was increased expression of SAA1 that is associated with leukocyte recruitment (Santos et al. 2009). CSF-1 is also synthesized in the epithelia of pregnant and lactating mammary glands and milk is a rich source of CSF-1 (Roth 1991; Sapi et al. 1998; Ryan et al. 2001). This epithelial CSF-1 synthesis is regulated by prolactin and progesterone (Sapi and Kacinski 1999). In the absence of CSF-1 in the Csf $1^{o p}$ null mutant mouse, there is an almost complete absence of macrophages in the pregnant and lactational glands suggesting that CSF-1 is a major chemoattractant and survival factor for these cells during these phases of development (Gouon-Evans et al. 2002).

Transcriptome analysis of total RNA extracted from mammary gland isolated during pregnancy and lactation also revealed a surprising number of immune mediators expressed at these stages. These include T-cell regulatory cytokines and acute phase proteins (Watson 2009). Some of these molecules (such as IL-4 and IL13), which under most circumstances act on immune cells, appear to play important roles by directly regulating mammary epithelial function (Khaled et al. 2007) whereas others synthesized by the mammary epithelium undoubtedly influence the immune cell population during pregnancy and lactation (Watson 2009). This plethora of immune mediators remains a fertile area both for discovery and for functional studies.

There are few functional studies on leukocytes during pregnancy and lactation except in their immune roles in response to infection, particularly in farm species (Wheeler et al. 1997a,b; Paape et al. 2002; Marshall et al. 2006; Atabai et al. 2007; Bleck et al. 2009). However, loss of CSF-1 in Csf $1^{o p / o p}$ mice results in a failure of ductal branching and premature differentiation of the lobuloalveolar structures with earlier expression of milk proteins than detected in wild-type mice (Pollard and Hennighausen 1994). This suggests a tradeoff between growth and differentiation during epithelial development. This effect can be partially rescued by recombinant CSF-1 administered subcutaneously (Pollard and Hennighausen 1994). These data showing that macrophage depletion results in a loss of ductal outgrowth during pregnancy reinforces the concept that macrophages have an important role in branching morphogenesis in the mammary gland. Ablation of immune cell types other than macrophages during pregnancy has not been reported and thus their roles in the processes of lobuloalveolar development and during lactation are unknown.

\section{INVOLUTION}

The cessation of suckling triggers involution in the mammary gland. Usually this occurs gradually and thus the process is not synchronized. 
However, synchronization can be achieved by abrupt removal of pups. This forced weaning model revealed two stages of involution. The first within 24 hours of pup removal is characterized by epithelial cell apoptosis-a process that can be reversed by re-exposure to pups causing lactation to continue. The second phase of involution at around $48 \mathrm{hr}$ postweaning involves massive apoptosis, matrix modeling and regression of the alveolar structure. With the loss of epithelial structures the gland is repopulated with adipocytes and eventually it returns to a virgin-like state (Atabai et al. 2007).

It was originally thought that the professional phagocytic macrophages would be recruited early in involution to ingest the apoptotic bodies. However, this does not appear to be the case (Monks and Henson 2009). Instead macrophage recruitment is only observed 3-4 days postweaning and instead of professional phagocytes, the removal of the early apoptotic bodies is effected through autophagy by adjacent epithelial cells (Monks and Henson 2009). In mice there is also evidence of neutrophils that are recruited before macrophages and, these cells together with macrophages are scattered through the interstitum and in the alveolar spaces (Monks et al. 2002; Atabai et al. 2007). In the human, cells bearing the pan-leukocytic marker CD45, are also found abundantly in the involuting gland (O'Brien and Schedin 2009). Similarly in farm species where it has been studied extensively, macrophages, neutrophils, and lymphocytes are found in the secretions from involuting glands. It is extremely likely that these macrophages scavenge debris and apoptotic cells (Atabai et al. 2007; Monks and Henson 2009) as well as bacteria (Tatarczuch et al. 2000, 2002). They may therefore be important in the prevention of mastitis in the vulnerable period of milk stasis (Atabai et al. 2007).

This sequential recruitment of neutrophils, macrophages, and lymphocytes at day 3-4 of involution is supported by the transcriptome analysis of involuting mammary glands. These data show expression of a wide range of inflammatory and acute phase molecules in the involuting mammary gland (Stein et al. 2004;
Watson 2009). At 3-4 d postweaning these include markers for monocytes and macrophages such as F4/80, Ly6c, CD11b CSF-1R, and CD14, as well as markers for alternatively activated tissue-remodeling macrophages such as Arginase 1 (Stein et al. 2004; Monks and Henson 2009; O'Brien and Schedin 2009). This is preceded by the expression of leukocytic chemoattractants including CCL6, CCL7, CCL8, and CXCL14 that are expressed $24 \mathrm{~h}$ postweaning (Clarkson et al. 2004). However, the exact role of these chemoattractive molecules remains to be determined.

The other functions of these immune cells in involution, apart from garbage clearance and immunity, remains elusive because transient depletions of particular populations have not been performed. Interestingly $C s f 1^{o p / o p}$ mice are unable to efficiently undergo a lactational switch and consequently there is a rapid involution in these mice (Pollard and Hennighausen 1994). However, this may be due less to the biology of the mammary gland and more to do with the failure of these mice to feed their young perhaps because of problems in olfaction required for pup finding (Erblich et al. unpubl.). Recent studies show that recruited macrophages are polarized to a tissue remodeling state and that their presence, just as in the developing gland, is associated with collagen deposition and matrix remodeling (O'Brien et al. 2010). Macrophages have also recently been shown to be important in adipogenesis at least during obesity, through their secretion of adipocyte growth factors and matrix remodeling molecules (Pollard 2009). However, whether they function as such during involution remains to be determined.

The intense remodeling of the mammary gland during involution associated with abundant macrophages may have negative consequences. This immediate postpartum period is associated with a higher risk of breast cancer that can manifest itself in a very aggressive form (O'Brien and Schedin 2009). Because macrophages play an important role in breast cancer progression and promotion of metastasis (see "Myeloid Cells and Breast Carcinogenesis") (Qian and Pollard 2010), it has been suggested 
that these cells during involution may encourage the growth of stem cells carrying oncogenic mutations through their effects on matrix remodeling and production of growth and angiogenic factors (Schedin 2006; O'Brien and Schedin 2009). Indeed, the matrix formed during early involution is tumor promoting in models of breast cancer when compared with virgin and late-involution matrix (McDaniel et al. 2006; O'Brien et al. 2010). Interestingly, this increased risk of breast cancer is transient and in the longer term, parity is protective. This has been suggested to be because of sustained expression of transforming growth factor (TGF)- $\beta 3$ (D'Cruz et al. 2002) that in many contexts is tumor inhibiting in part through effects on stem cell senescence (Boulanger and Smith 2001) and inhibition of mammary epithelial cell proliferation (Ewan et al. 2002). TGF 33 is one of the earliest signaling molecules starting involution by stimulating apoptosis and it is expressed in two waves through involution (Nguyen and Pollard 2000). Coincidently macrophages are also important TGF $\beta$ producing and modifying cells suggesting that they may have dual roles in cancer risk dependent on context.

\section{IMMUNE CELLS AND BREAST CANCER DEVELOPMENT}

Breast cancer $(\mathrm{BrCa})$ is the most frequent malignant tumor of women in North America (Society 2007). Although genetic and epigenetic changes in genes that regulate mammary epithelial cell (MEC) proliferation, survival, polarity, and/or differentiation are likely "initiators" of breast carcinogenesis, several lines of evidence indicate that stromal cell responses in premalignant mammary tissue may "promote" progression to cancer and/or metastatic capability of malignant MECs. Cellular components of tumor stroma include (myo)fibroblasts, vascular cells, infiltrating leukocytes, and specialized mesenchymal support cells unique to each tissue microenvironment.

Although $\mathrm{BrCa}$ has not historically been linked to underlying inflammation or infection, it shows tumor-associated inflammation as defined by infiltration of leukocytes into developing tumors where increases in some immune cell subsets in neoplastic stroma parallels disease progression (de Visser et al. 2006; DeNardo and Coussens 2007; DeNardo et al. 2009). Breast cancer development in woman is characterized by a significant increase in the presence of both innate and adaptive immune cells, with $\mathrm{B}$ and $\mathrm{T}$ lymphocytes as well as macrophages representing the most abundant leukocytes present in neoplastic stroma (DeNardo and Coussens 2007) (Fig. 5). Retrospective clinical studies examining identity of leukocytes in human breast cancer have revealed that high immunoglobulin (Ig) levels in tumor stoma (and serum), and increased presence of extrafollicular $\mathrm{B}$ cells, $\mathrm{T}$ regulatory $\left(\mathrm{T}_{\mathrm{reg}}\right)$ cells, high ratios of $\mathrm{CD} 4 / \mathrm{CD} 8$, or $\mathrm{T}_{\mathrm{H}} 2 / \mathrm{T}_{\mathrm{H}} 1 \mathrm{~T}$ lymphocytes in primary tumors or in draining lymph nodes correlates with tumor grade, stage, and overall patient survival (Shimokawara et al. 1982; Lee et al. 1985; Chin et al. 1992; Punt et al. 1994; Coronella et al. 2001; Coronella-Wood and Hersh 2003; Fernandez Madrid 2005; Kohrt et al. 2005; Bates et al. 2006); thus, some facets of adaptive immunity may indeed be involved in fostering cancer development in the breast. On the other hand, clinical (Leek and Harris 2002) studies show association with poor prognosis and experimental studies have shown that macrophages in primary mammary adenocarcinomas regulate early tumor development by activating angiogenic programs, as well as latestage carcinogenesis by virtue of their secretion of paracrine factors required for stimulating proinvasive and prometastatic programs in malignant mammary epithelial cells (MECs) (Lin et al. 2001; Wyckoff et al. 2004, 2007; Goswami et al. 2005; Lin and Pollard 2007; Wang et al. 2007; Philippar et al. 2008; Yang et al. 2008; DeNardo et al. 2009; Gocheva et al. 2010).

\section{MYELOID CELLS AND BREAST CARCINOGENESIS}

Myeloid-lineage immune cells, such as mast cells, macrophages, and neutrophils, have been shown to promote tumor progression by exerting a number of protumoral activities, e.g., by stimulating angiogenesis (Coussens et al. 1999; 

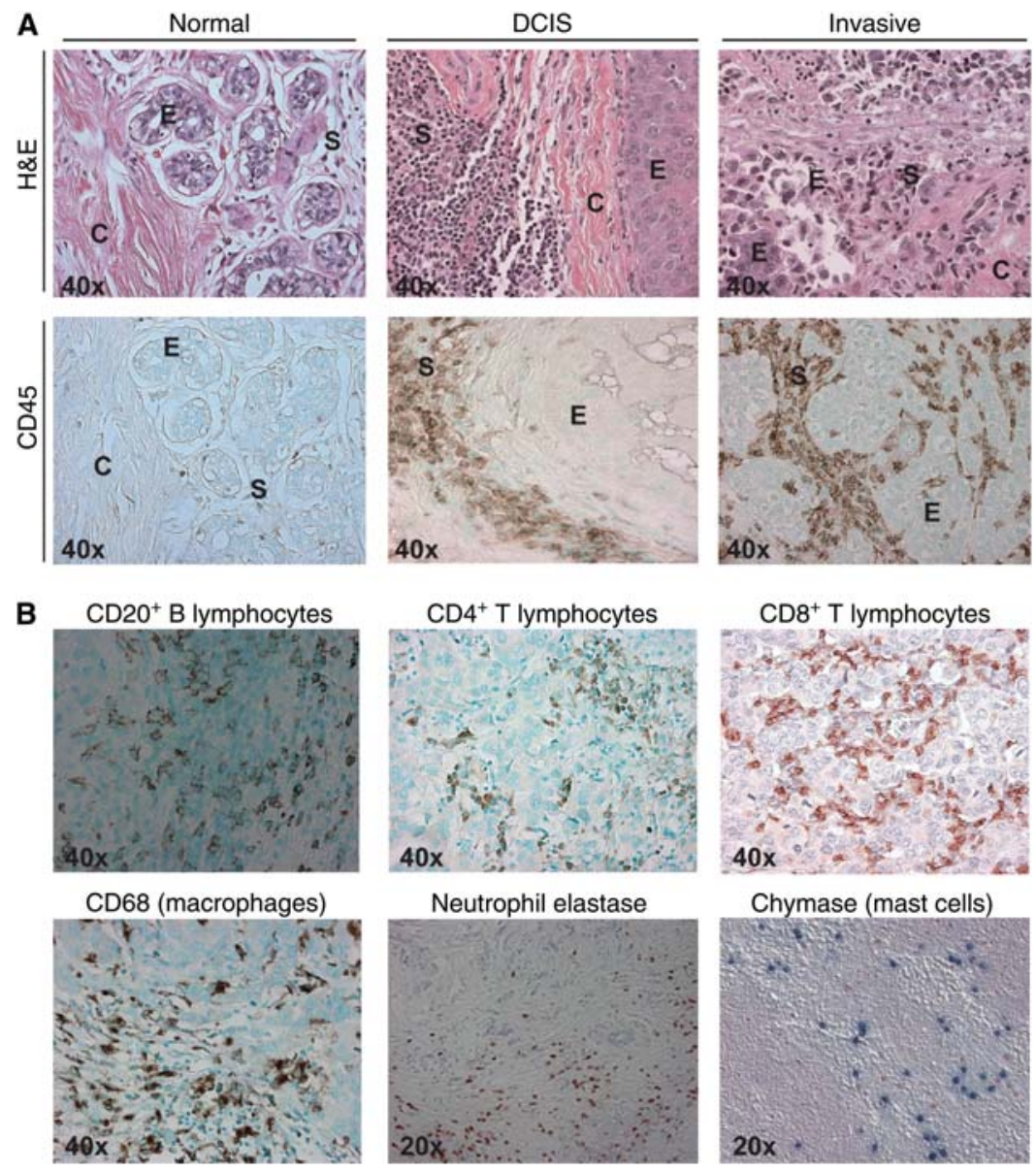

Figure 5. Leukocytes in human breast, ductal carcinoma in situ, and invasive carcinoma. (A) Hematoxylin and Eosin (H\&E; top row) staining of normal human breast tissue, ductal carcinoma in situ (DCIS) and invasive breast cancer (invasive), showing ductal epithelial structures (E), collagenous stroma (C), and darkly stained immune cells infiltrating stroma (S). Immunodetection of infiltrating leukocytes by CD45 (leukocyte common antigen) immunoreactivity (brown staining; bottom row) reveals significant leukocyte infiltration in DCIS and invasive cancer, as compared to normal breast tissue. (B) Imunodetection of specific lineages of immune cells in invasive breast cancer, B lymphocytes $\left(\mathrm{CD} 20^{+}\right.$; brown staining), $\mathrm{CD} 4^{+} \mathrm{T}$ lymphocytes (brown staining), $\mathrm{CD} 8^{+}$ T lymphocytes (brown staining), macrophages $\left(\mathrm{CD} 8^{+}\right.$; brown staining), neutrophils (neutrophils elastase ${ }^{+}$; brown staining), and mast cells (chymase ${ }^{+}$; blue staining). Original magnifications are shown for each panel.

De Palma et al. 2005; Okamoto et al. 2005; Lin et al. 2006; Nozawa et al. 2006; Takakura 2006; Lin and Pollard 2007), suppressing antitumor immunity (Blankenstein 2005; Zou 2005; Bronte et al. 2006), and enhancing tumor cell migration and metastasis (Wyckoff et al. 2004; Condeelis and Pollard 2006; DeNardo et al. 2009; Gocheva et al. 2010). Nucleated hematopoietic cells that have been directly implicated in tumor angiogenesis include mast cells
(Coussens et al. 1999; Soucek et al. 2007), tumor-associated macrophages (Pollard 2004; Balkwill et al. 2005; Lewis and Pollard 2006), Tie2-expressing monocytes (De Palma et al. 2005; De Palma and Naldini 2006), neutrophils (Nozawa et al. 2006), dendritic cell precursors (Coukos et al. 2005), and myeloid immune suppressor cells (Yang et al. 2004; Serafini et al. 2006). Other hematopoietic cell types, such as platelets (Kisucka et al. 2006), eosinophils 
(Puxeddu et al. 2005), and hematopoietic progenitors (Takakura et al. 2000), also participate in angiogenic processes, but it remains to be established whether they can directly promote tumor angiogenesis, rather than having a broader function in supporting tissue inflammation and remodeling.

The potential of neoplastic cells to spread locally (i.e., progress to malignancy) and systemically (i.e., metastasize) is linked to activation of angiogenic vasculature (Hanahan and Weinberg 2000). Tumor-associated blood vessels generated by angiogenesis support tumor growth and development, as well as provide escape routes for malignant cells to intravasate into the circulation (Hanahan and Weinberg 2000; Wyckoff et al. 2007). Although several studies have found that some highly metastatic breast cancer cell lines have up-regulated expression of genes encoding proangiogenic factors such as vascular endothelial growth factor (VEGF) that favor activation of angiogenic vessels (Lee et al. 2007), tumor angiogenesis in the mammary gland, as well as in other organs, is likely initially activated by activated myeloid cells attracted to neoplastic tissue (Coussens et al. 1999; Bergers et al. 2000; Condeelis and Pollard 2006).

In breast carcinomas, macrophages are one of the most abundant innate immune cell types in which they enhance angiogenic programming by production of proangiogenic factors such as VEGF and proteases, i.e., urokinasetype plasminogen activator (uPA) and MMP9 (Lin and Pollard 2007). In a mouse model of mammary adenocarcinoma development, e.g., MMTV-PyMT mice (Guy et al. 1992), increased macrophage infiltration in premalignant tissue occurs immediately before the angiogenic switch and the onset of malignancy (Lin et al. 2001, 2006). CSF-1 is broadly expressed by tumors of the reproductive system and its expression correlates with the extent of leukocyte infiltration and represent a poor prognostic indicator in these tumors (Lin and Pollard 2004). By using PyMT mice carrying a Csf1 null mutation $\left(C s f 1^{o p / o p}\right)$, it was further shown that depletion of CSF-1 markedly decreased infiltration of macrophages at tumor sites, inhibited the angiogenic switch and significantly delayed tumor progression. The knockdown of CSF-1 in transplanted tumor cells (by using antisense oligonucleotides) also resulted in inhibition of tumor growth, with tumors showing extensive necrosis and poor vascularization, phenotypes that could be reversed by treatment of mice with CSF-1. The premature macrophage infiltration in the mammary gland of MMTVLTR-CSF-1 transgenic mice induced robust angiogenesis even at early pre-malignant stages, providing evidence for a direct link between macrophage infiltration and angiogenesis, independent of tumor stage (Lin et al. 2006). These studies have provided evidence that CSF-1 is a major regulator of macrophage recruitment to tumors and shed light on the important roles of macrophages in tumor progression, and in particular with tumor-associated angiogenesis. Myeloid cell-delivery of VEGF to mammary tumors is clearly significant because myeloidspecific deletion of VEGF inhibited the angiogenic switch but surprisingly accelerated tumor development (Stockmann et al. 2008). In this regard, myeloid VEGF regulates formation of high-density vessel networks, attenuation of which blocks angiogenic programming of tumors while also inducing normalization of vasculature that thus results in accelerated tumor progression by decreasing tumor cell death and tumor hypoxia, together indicating that myeloid-derived VEGF-A is essential for tumor-associated alterations of vasculature. It is known that macrophages heavily infiltrate necrotic areas in tumors where they scavenge cellular debris and cooperate with tumor cells to promote angiogenesis (Murdoch et al. 2004; Lewis and Murdoch 2005). In fact, hypoxia stimulates expression of several proangiogenic molecules by activating hypoxia-inducible factors (HIFs) in macrophages. Expression of the monocyte chemoattractantss VEGF, endothelin 2, and endothelial monocyte-activating polypeptide II (EMAP II) by hypoxic tumor cells can attract macrophages into hypoxic areas within tumors. It is believed that macrophages are then retained in hypoxic tumor areas because of abrogation of chemotactic signal transduction and the down-regulation 
of chemo-attractant receptors. Once in hypoxic areas, macrophages produce a wide array of proangiogenic molecules and matrix-remodeling factors, including IL-8/CXCL8, VEGF, FGF, platelet-derived growth factor (PDGF), MMPs, and uPA, but it remains to be clarified how crucial these macrophage-secreted factors are in the economy of tumor angiogenesis, because many proangiogenic molecules are also produced by other components of the tumor stroma and by the tumor cells themselves.

In addition to the aforementioned proangiogenic factors, macrophages release other molecules that can influence angiogenesis (Pollard 2004; Ojalvo et al. 2009). Macrophages are key producers of TNF- $\alpha$, that can up-regulate expression of thymidine phosphorylase and MMP-9. Macrophages also produce IL-1 that may increase VEGF transcription by up-regulating expression of HIF-1 $\alpha$ through cyclooxygenase (COX)-2. In addition, macrophages also release nitric oxyde (NO), a molecule that provokes vasodilation and increased vascular flow, through the activity of inducible NO synthase (iNOS). Macrophages can also produce FGF, hepatocyte growth factor (HGF), other EGFR ligands (HB-EGF), as well as plateletderived growth factor (PDGF) and TGF $\alpha$ (Condeelis and Pollard 2006). In particular, leukocyte-derived tumor necrosis factor (TNF) $\alpha$ has been found to enhance invasive/migratory phenotypes of breast cancer cells in culture (Hagemann et al. 2005). In breast cancer cell lines, $\mathrm{TNF} \alpha$ regulates epithelial invasion through activation of downstream signaling cascades including Jun amino-terminal kinase (JNK) and nuclear factor $\kappa \mathrm{B}(\mathrm{NF \kappa B})$ transcription factor. Activated JNK and NFKB in turn induce gene expression of proinvasive factors such as EMMPRIN (extracellular matrix metallo-protease inducer) and MIF (migration inhibitory factor), whose expression enhances MMP-2 and -9 secretion and activity (Hagemann et al. 2005). Production of TGF $\beta$ by alternatively activated macrophages in mammary tumors, mesenchymal support cells, and immature myeloid cells (IMCs) can also enhance the invasive and metastatic programming of malignant cells (Stover et al. 2007; Bierie et al. 2008;
Yang et al. 2008) consistent with existence of a TGF $\beta$-responsive gene signature that a predicts breast cancer pulmonary metastasis (Arribas et al. 1997).

Another myeloid population recently implicated in tumor angiogenesis are the so-called immature myeloid suppressor cells (Gallina et al. 2006; Serafini et al. 2006). Myeloid suppressor cells express low to undetectable levels of MHC-II and costimulatory molecules, thus cannot induce antitumor responses. Rather, these cells promote tumor development by exerting a profound inhibitory activity on both tumor-specific and nonspecific T lymphocytes and, as recently described, by providing factors essential for tumor growth and neovascularization such as TGF $\beta$ (Yang et al. 2004, 2008). The frequency of myeloid suppressor cells is significantly increased in the bone marrow $(\mathrm{BM})$ and spleen of cancer patients and mice carrying large tumors. Moses and colleagues (Yang et al. 2004) found that $\mathrm{CD}_{11 b^{+}} \mathrm{Gr}^{+}{ }^{+}$ myeloid suppressor cells obtained from spleens of tumor-bearing mice promoted angiogenesis and tumor growth when co-injected with tumor cells, largely in response to their high level secretion of TGF $\beta$ (Yang et al. 2008). Myeloid suppressor cells also produce high levels of MMP-9, deletion of which minimizes their tumor-promoting activity. Similar to DC precursors, $\mathrm{CD}_{11 \mathrm{~b}^{+} \mathrm{Gr}^{+}}{ }^{+}$cells have also been found to occasionally incorporate into tumor endothelium as endothelial-like cells (Yang et al. 2004).

Concentration gradients of growth factors established by leukocytes present in neoplastic stroma coordinate tumor cell movements toward, and intravasation into, tumor-associated vasculature. For example, macrophages are the primary source of EGF in breast cancer microenvironments (Leek et al. 2000; Lewis and Pollard 2006). EGF promotes invasion/ chemotaxis and intravasation of breast carcinoma cells through its interaction with EGFR as shown using an in vivo needle chemotaxis assay through engagement of cofilin-dependent actin polymerization (Wyckoff et al. 2000; Wang et al. 2007). Paracrine interactions between macrophages and breast carcinoma cells form positive feed-forward loops involving 
macrophage-expressed EGF and CSF-1 expressed by neoplastic cells, that together result in breast carcinoma cells showing "high-velocity" polarized movement (chemotaxis) along collagen fibers toward blood vessels directed by perivascular macrophages (Condeelis and Segall 2003; Condeelis and Pollard 2006). These experimental data combined with the positive correlation between CSF-1 levels, macrophage recruitment and poor prognosis in human cancers (Scholl et al. 1994; Leek and Harris 2002), together support the notion that macrophages and/or their products play a major role in facilitating late-stage metastatic progression of tumors (Lin et al. 2001). Significantly a stromal CSF-1 gene expression signature in breast cancer correlated with poor outcomes and was observed to be similar between primary tumors and lymph node metastases (Webster et al. 2010).

Similar to CSF-1, several CC chemokines, particularly CCL2 and CCL5 (RANTES, or regulated on activation normal $\mathrm{T}$ cells expressed and secreted), have been implicated in recruitment of monocytes to tumors (Lin and Pollard 2004). CCL2/MCP-1 overexpression by genetically modified tumor cells implanted in mice promoted monocyte uptake by the tumor mass. In human tumors, CCL2/MCP-1 and CCL5/RANTES are produced predominately by neoplastic cells and fibroblasts correlating with macrophage infiltration. Furthermore, both CCL2/MCP-1 and CCL5/RANTES have been found to stimulate monocyte/macrophage-lineage cells to secrete MMP-9 and urokinase-type plasminogen activator (uPA), which through their ECM-remodeling functions are potent activators of angiogenesis (Murdoch et al. 2004). Thus, thanks to their ability to attract proangiogenic monocytes/macrophages to tumors, both CSF-1 and CCL2/MCP-1 can be regarded as major players in the orchestration of the angiogenic process in tumors.

\section{T LYMPHOCYTES AND BREAST CANCER}

Clinical evaluation of human breast adenocarcinomas reveals that presence of $\mathrm{CD} 4{ }^{+} \mathrm{T}_{\mathrm{H}} 2 \mathrm{~T}$ cells and $\mathrm{T}_{\text {reg }}$ cells increases with disease progression.
High percentages of $\mathrm{CD} 4^{+} \mathrm{T}$ cells in primary breast cancers positively correlate with markers of disease progression, including metastatic spread to sentinel lymph nodes and increased primary tumor size (Chin et al. 1992; Kohrt et al. 2005). The extent of T-cell infiltration into invasive breast carcinomas has been reported to range from $1 \%-45 \%$ of the total cellular mass (Chin et al. 1992). In rapidly proliferating tumors, presence of $\mathrm{T}$ lymphocytes (by histopathological determination) at tumor sites is a good prognostic indicator when compared to nonimmunogenic tumors, and correlates with auxillary lymph node negativity, smaller tumor diameter, lower histological grade, and recurrence-free survival (Aaltomaa et al. 1992); thus, supporting an overall role for $\mathrm{T}$ cells in immune surveillance. However, the exact composition of T-lymphocyte infiltration varies greatly and may profoundly affect disease progression and overall patient survival. Perhaps more significant, the ratio of $\mathrm{CD} 4^{+}$to $\mathrm{CD}^{+} \mathrm{T}$ cells or $\mathrm{T}_{\mathrm{H}} 2$ to $\mathrm{T}_{\mathrm{H}} 1$ cells present in primary tumors, where $\mathrm{CD}^{+}$or $\mathrm{T}_{\mathrm{H}} 2$ cells are more frequent than $\mathrm{CD}^{+}$or $\mathrm{T}_{\mathrm{H}} 1$ cells, correlates with lymph node metastasis and reduced overall patient survival (Chin et al. 1992; Kohrt et al. 2005). More recently, unsupervised expression profiling from breast cancer-associated stroma revealed a gene signature predictive of good prognostic outcome ( $>98 \%$, 5-year survival) that was functionally enriched for elements of a $\mathrm{T}_{\mathrm{H}} 1$-type immune response, including genes suggestive of cytotoxic $\mathrm{T}$ lymphocyte (CTL) and natural killer (NK) cell activity (Finak et al. 2008). Conversely, high levels of $\mathrm{FOXP}^{+} \mathrm{T}_{\text {reg }}$ cells predict diminished relapsefree and overall patient survival (Bates et al. 2006, 2007). Although it is unclear if presence of $\mathrm{CD}^{+}$CTLs alone provides any prognostic information for breast cancer, the presence of high percentages of $\mathrm{CD}^{+}{ }^{+} \mathrm{T}$ helper cells at primary tumor sites positively correlates with disease progression, e.g., metastatic spread to sentinel lymph node (LN) and primary tumor size (Chin et al. 1992; Kohrt et al. 2005). The interpretation based on these clinical studies is that the type of $\mathrm{CD}^{+}{ }^{+}$effector T-cell response elicited in an emergent breast cancer may in 
part determine malignant and metastatic potential. Although presence of metastatic MECs in sentinel lymph nodes draining the primary tumor represents the strongest prognostic indicator for disease progression and overall patient outcome, combinatorial analysis evaluating presence and composition of leukocytes, together with other clinical markers indicative of stage, may provide utility for predicting outcome.

Why are $\mathrm{CD}^{+}$CTL-mediated responses not more effective in eradicating or minimizing cancer occurrence and how might $\mathrm{CD} 4^{+} \mathrm{T}$ cells be involved in enhancing breast cancer progression? One plausible mechanism may have to do with the "polarity" of the $\mathrm{CD} 4^{+} \mathrm{T}_{\text {helper }}$ cell response at primary tumor sites and/or their distant metastases. We recently reported that interleukin (IL)-4-expressing $\mathrm{T}_{\mathrm{H}} 2 \mathrm{CD}^{+}{ }^{+} \mathrm{T}$ lymphocytes promote invasion and metastasis of mammary adenocarcinomas by directly regulating $\mathrm{T}_{\mathrm{H}} 2$ activity in macrophages, their bioeffector function and EGF expression, that in turn regulate invasive tumor growth, presence of circulating tumor cells (CTCs), and pulmonary metastasis (DeNardo et al. 2009). Using the PyMT mouse model of mammary carcinogenesis (Guy et al. 1992), we found that whereas primary tumor development was unchanged in PyMT $/ \mathrm{CD}^{-/-}$mice, both showed a significantly attenuated metastatic phenotype (DeNardo et al. 2009) similar to that of tissue macrophage-deficient/PyMT mice (Lin et al. 2001). We found that $\mathrm{CD} 11 \mathrm{~b}^{+} \mathrm{Gr} 1^{+}$monocytes and macrophages of CD4-deficient/PyMT tumors expressed significantly elevated levels of type 1 cytokines (e.g., TNF $\alpha$, IL-6, IL$12 \mathrm{p} 40$, and IL-1 $\beta$ ) and Nos $2 \mathrm{mRNA}$, indicative of a prevalent $\mathrm{T}_{\mathrm{H}} 1$ immune microenvironment and M1 phenotype (DeNardo et al. 2009),

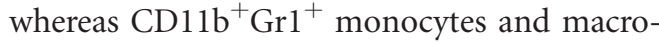
phages from CD4-proficient/PyMT mice were instead indicative of alternatively activated M2 cells that expressed higher levels of arginase-1 (Arg-1) and $\operatorname{Tgf} \beta$, thus characterizing a $\mathrm{T}_{\mathrm{H}} 2$ microenvironment (DeNardo et al. 2009). To determine if $\mathrm{CD}^{+}$T-cell regulated myeloid cell phenotypes by a $\mathrm{T}_{\mathrm{H}} 2$ pathway, we evaluated $\mathrm{CD}^{+}{ }^{+} \mathrm{T}$ cells from LNs and carcinomas of
Leukocytes in Mammary Development and Cancer

PyMT mice and found elevated expression of GATA3, IL-4, IL-13, and IL-10 $\left(\mathrm{T}_{\mathrm{H}} 2\right)$ and to a lesser extent T-bet $\left(\mathrm{T}_{\mathrm{H}} 1\right)$ and the $\mathrm{T}_{\mathrm{H}} 1$ cytokine IFN $\gamma$, but neither FOXP3 $\left(\mathrm{T}_{\text {reg }}\right)$ nor IL-17a were expanded as compared to wild-type littermates indicating presence of both $\mathrm{T}_{\mathrm{H}} 1$ and $\mathrm{T}_{\mathrm{H}} 2$ effector lineages.

PyMT/IL4R $\alpha$-deficient mice and PyMT mice treated with neutralizing antibodies to IL-4 phenocopied PyMT/CD4-deficient mice with diminished pulmonary metastasis and presence of M1-CD11b ${ }^{+} \mathrm{Grl}^{+}$monocytes and macrophages in carcinomas (DeNardo et al. 2009). Moreover, Joyce and colleagues recently reported that IL-4 activation of tumorassociated macrophages was significant for cathepsin B and S production, that together also enhance invasion and metastatic progression (Gocheva et al. 2010). Together this data indicates that $\mathrm{T}_{\mathrm{H}} 2-\mathrm{CD} 4{ }^{+} \mathrm{T}$ cells promote metastasis by enhancing the protumor bioactivities of macrophages, and engaging intracellular signaling cascades (EGF) required for dissemination and metastasis and indicating that blockade of $\mathrm{T}_{\mathrm{H}}$ 2-based and/or IL-4/IL-13regulated pathways may provide a survival advantage by limiting late-stage disease progression and metastatic spread. By comparison, loss of $\mathrm{CD}^{+} \mathrm{T}$ lymphocytes, similarly to loss of macrophage recruitment to mammary tumors, results in reduced presence of CTCs and diminished development of pulmonary metastasis, but without impacting microvessel density or the character of angiogenic vasculature in mammary carcinomas. These distinctions reflect the fact that $\mathrm{CD} 4^{+} \mathrm{T}$ lymphocyte-derived factors, including IL-4, partially regulate the protumor properties of macrophages, in particular a unique population that promotes invasion and metastasis (Ojalvo et al. 2010), likely because of their impact on EGF expression. Therefore, the proangiogenic properties of macrophages are regulated independently of their $\mathrm{T}_{\mathrm{H}} 1-$ or $\mathrm{T}_{\mathrm{H}} 2$ type cytokine expression characteristics, and instead are more likely dependent on other factors such as hypoxia (Lewis and Murdoch 2005; Zinkernagel et al. 2007).

In addition to indirectly potentiating cancer development by regulating protumor properties 
of myeloid cells, work from several groups have reported that IL-4 and IL-13 also regulate tumor growth directly through activation of IL-4/13 receptors on epithelial cells. In some human breast carcinoma cell lines, particularly those that express the estrogen receptor $\alpha$, IL-4, and IL-13 inhibit both basal and estrogeninduced cell proliferation in vitro and in xenograph tumor models in vivo (Toi et al. 1992; Gingras et al. 2000; Nagai and Toi 2000; Gooch et al. 2002). However, in other breast carcinoma cell lines, IL-4 regulates tumor cell survival by conferring resistance to apoptosis (in vitro) that translates to resistance to chemotherapy in xenograph models (Todaro et al. 2008). Palucka and colleagues reported that $\mathrm{CD}^{+} \mathrm{T}$ cells directly enhance early breast tumor development in xenograph tumors using humanized NOD/SCID mice, and reported that the ability of $\mathrm{CD}^{+}{ }^{+}$cells to produce $\mathrm{T}_{\mathrm{H}} 2$ cytokines including IL-4 and IL-13 was key (Aspord et al. 2007). Taken together these data indicate that the effects of CD4-derived $\mathrm{T}_{\mathrm{H}} 2$ cytokines on tumor development and progression is likely regulated by the organ microenvironment or IL-4/13 receptor status of malignant cells, and may also be subject to tumor cell etiology and the specific genetic programs altered during the initiation phase of cancer development. This realization, however, has profound implications for development of future therapeutics targeting $\mathrm{CD}^{+} \mathrm{T}$ cells to either bolster antitumor immunity or neutralize protumor immunity by revealing the complexities of their bioeffector functions that are regulated by multiple factors not common to all tumor models.

\section{B LYMPHOCYTES, HUMORAL IMMUNITY, AND BREAST CANCER}

During breast carcinogenesis, mature B cells (including naive and activated) can be found in secondary lymphoid tissues as well as in tumor-associated stroma. As compared to healthy patients without evidence of cancer, the sentinel (draining) LNs of breast cancer patients contains enriched populations of proliferating and affinity matured $\left(\mathrm{IgG}^{+}\right) \mathrm{B}$ lymphocytes. Moreover, data from retrospective studies examining percentages of $B$ cells present in sentinel and auxiliary LNs of breast cancer patients reveals that their presence and/or maturation $\left(\mathrm{IgG}^{+}\right)$correlates with increases in disease stage (stage I versus stage II) and total tumor burden (Wernicke 1975). UrdialesViedma and colleagues used immunohistochemical detection of IgA, IgG, and IgM in axillary LNs from 50 unselected ductal breast carcinomas and found that LNs with $\mathrm{IgG}^{+} \mathrm{lym}$ phoid follicles and/or metastatic LNs with $\mathrm{IgM}^{+}$lymphoid cells were statistically related to breast tumors of high histologic grade and more than three LN metastases (UrdialesViedma et al. 1986). These data correlate the presence of various populations of B cells in lymph nodes with malignancy.

During breast cancer development, Ig deposition in neoplastic mammary stroma is known to increase the bioavailability of VEGF by Ig binding to FcRs on tumor-associated macrophages and thus triggering release VEGF into the interstitium (Barbera-Guillem et al. 2002). Moreover, in breast carcinoma tissues, presence of endocytosed Ig in macrophages corresponds with local extracellular VEGF protein levels and local angiogenic vascular buds (BarberaGuillem et al. 2002).

How might B lymphocytes regulate carcinoma development? A vast literature exists describing the occurrence of (auto)antibodies in either the serum of cancer patients, or interstitial antibody deposition in tumors (Tomer et al. 1998). Early presence of autoantibodies (in particular antinuclear and smooth muscle antibodies) in serum of cancer patients is well known to correlate with unfavorable prognosis (Tan and Shi 2003). Approximately 50\% of breast cancer patients contain circulating Igs that specifically react with tumor-derived antigens-autoantibodies against ErbB2/HER2/ neu are present in $20 \%$ of patients with ErbB2positive breast cancer, making it the most common breast cancer "auto-antigen" (Disis et al. 1994). Paradoxically, presence of specific autoantibodies in serum and/or at tumor sites correlates with poor patient survival (Tomer et al. 1998; Tan and Shi 2003; Fernandez Madrid 
2005); thus, perhaps indicating that Igs resulting from chronic B cell activation in response to tumor-specific antigens might promote disease progression. Despite the presence of antitumor antibodies in greater than half of all breast cancer patients, there are only few reports of spontaneous tumor regression (presumed to be immunologic) in the absence of therapy (Sheikh et al. 1979; Lee et al. 1985). Several factors may influence efficiency of antitumor antibodies in inducing tumor regression/destruction, including Ig concentration, HLA expression, tumor tolerance/immune suppression, and impaired cytotoxic T-cell activity. Thus, whether individuals with progressing tumors harbor a higher antigen load that thus triggers enhanced Ig production, or whether increased presence of serum or interstitial Igs predisposes patients to development of more advanced or recurrent cancers, requires further study. That said, B-cell-depletion in MMTV-PyMT mice was shown to be without consequence in regulating early or late-stage mammary carcinogenesis (DeNardo et al. 2009).

\section{CONCLUSIONS}

During the last decade, insights have been gained regarding mechanisms underlying the dynamic roles of immune cells as mediators of developmental processes, tissue homeostasis in adult tissues, and tumorigenesis. During the various phase of mammary development the immune system is engaged at every stage. This response appears to be restricted to the innate immune system except during lactation. Although these cells of the innate system are called immune cells this attribution appears to be a misnomer in these developmental contexts as there are no pathogens present. Instead these cells are trophic to developing tissue and act to enhance rates of epithelial growth and invasion through the fat pad and influence complexity of the ductal structures (Pollard 2009). During tumorigenesis a similar cast of innate immune cells are recruited. However in contrast to the developmental context there is a much greater engagement of the acquired immune response. This presence of many acquired immune cells in tumors suggests recognition of new "foreign" tumor antigens or of the extensive tissue damage caused by tumor growth. Indeed in some cases a tumor-directed immune response involving cytolytic $\mathrm{CD} 8^{+} \mathrm{T}$ cells, $\mathrm{T}_{\mathrm{H}} 1$ cells, and NK cells appears to protect against tumor development and progression. However, if the immune response involves $B$ cells and activation of humoral immunity, and infiltration of $\mathrm{T}_{\mathrm{H}} 2$ cells as well as innate inflammatory cells into an organ harboring initiated tumor cells, the likely outcome is promotion of tumor development and progression. Thus innate and acquired immune cells are in an evolving dynamic that result in the trophic functions of the innate system being conferred on the epithelial tumors in a fashion that mimics development. In mammary cancers of both mice and women macrophages appear to be the dominant innate immune cell type. Differing populations of macrophages confer on the tumor an ability to outgrow, invade, and become vascularized. Unfortunately unlike the developing mammary gland that has intrinsic programs to suppress the external trophic support once it is no longer required, the oncogenic and tumor suppressor mutations in cancer cells result in the loss of these "off" switches. Consequently the tumors obtain continuing support from these recruited immune cells and malignancy is enhanced. However, the balance between a protective cytotoxic response and a harmful humoral or $\mathrm{T}_{\mathrm{H}} 2$ response can be regulated systemically by the general immune status of the individual, as well as locally by myeloid suppressor cells and $\mathrm{T}_{\text {reg }}$ cells, and thus offers clinicians with attractive targets for anticancer immune-based therapies.

\section{ACKNOWLEDGMENTS}

The authors thank members of their laboratories for critical reading of the manuscript and constructive discussions. Work in the authors' laboratories is supported by the National Cancer Institute and the Department of Defense. 
L.M. Coussens and J.W. Pollard

\section{REFERENCES}

Aaltomaa S, Lipponen P, Eskelinen M, Kosma VM, Marin S, Alhava E, Syrjanen K. 1992. Tumor size, nuclear morphometry, mitotic indices as prognostic factors in axillary-lymph-node-positive breast cancer. Eur Surg Res 24: 160-168.

American Cancer Society. 2007. Cancer facts and figures. http://www.cancer.org/downloads/STT/caff2007PWSecured.pdf.

Anbazhagan R, Bartek J, Monaghan P, Gusterson BA. 1991. Growth and development of the human infant breast. Am $J$ Anat 192: 407-417.

Arribas J, Lopez-Casillas F, Massague J. 1997. Role of the juxtamembrane domains of the transforming growth factor- $\alpha$ precursor and the $\beta$-amyloid precursor protein in regulated ectodomain shedding. J Biol Chem 272: $17160-17165$.

Aspord C, Pedroza-Gonzalez A, Gallegos M, Tindle S, Burton EC, Su D, Marches F, Banchereau J, Palucka AK. 2007. Breast cancer instructs dendritic cells to prime interleukin 13-secreting CD4 + T cells that facilitate tumor development. J Exp Med 204: 1037-1047.

Atabai K, Sheppard D, Werb Z. 2007. Roles of the innate immune system in mammary gland remodeling during involution. J Mammary Gland Biol Neoplasia 12: 37-45.

Balkwill F, Charles KA, Mantovani A. 2005. Smoldering and polarized inflammation in the initiation and promotion of malignant disease. Cancer Cell 7: 211-217.

Barbera-Guillem E, Nyhus JK, Wolford CC, Friece CR, Sampsel JW. 2002. Vascular endothelial growth factor secretion by tumor-infiltrating macrophages essentially supports tumor angiogenesis, and IgG immune complexes potentiate the process. Cancer Res 62: 7042-7049.

Bates GJ, Fox SB, Han C, Launchbury R, Leek RD, Harris AL, Banham AH. 2007. Expression of the forkhead transcription factor FOXP1 is associated with that of estrogen receptorbeta in primary invasive breast carcinomas. Breast Cancer Res Treat 111: 453-459.

Bates GJ, Fox SB, Han C, Leek RD, Garcia JF, Harris AL, Banham AH. 2006. Quantification of regulatory T cells enables the identification of high-risk breast cancer patients and those at risk of late relapse. J Clin Oncol 24: 53735380 .

Bergers G, Brekken R, McMahon G, Vu TH, Itoh T, Tamaki K, Tanzawa K, Thorpe P, Itohara S, Werb Z, et al. 2000. Matrix metalloproteinase- 9 triggers the angiogenic switch during carcinogenesis. Nat Cell Biol 2: 737-744.

Bierie B, Stover DG, Abel TW, Chytil A, Gorska AE, Aakre M, Forrester E, Yang L, Wagner KU, Moses HL. 2008. Transforming growth factor-beta regulates mammary carcinoma cell survival and interaction with the adjacent microenvironment. Cancer Res 68: 1809-1819.

Blankenstein T. 2005. The role of tumor stroma in the interaction between tumor and immune system. Curr Opin Immunol 17: 180-186.

Bleck GT, Wheeler MB, Hansen LB, Chester-Jones H, Miller DJ. 2009. Lactose synthase components in milk: Concentrations of $\alpha$-lactalbumin and $\beta 1$,4-galactosyltransferase in milk of cows from several breeds at various stages of lactation. Reprod Domest Anim 44: 241-247.
Boulanger CA, Smith GH. 2001. Reducing mammary cancer risk through premature stem cell senescence. Oncogene 20: $2264-2272$.

Brandtzaeg P. 2010. Function of mucosa-associated lymphoid tissue in antibody formation. Immunol Invest 39: 303-355.

Bronte V, Cingarlini S, Marigo I, De Santo C, Gallina G, Dolcetti L, Ugel S, Peranzoni E, Mandruzzato S, Zanovello P. 2006. Leukocyte infiltration in cancer creates an unfavorable environment for antitumor immune responses: A novel target for therapeutic intervention. Immunol Invest 35: 327-357.

Chin Y, Janseens J, Vandepitte J, Vandenbrande J, Opdebeek L, Raus J. 1992. Phenotypic analysis of tumor-infiltrating lymphocytes from human breast cancer. Anticancer Res 12: $1463-1466$.

Clarkson RW, Wayland MT, Lee J, Freeman T, Watson CJ. 2004. Gene expression profiling of mammary gland development reveals putative roles for death receptors and immune mediators in post-lactational regression. Breast Cancer Res 6: R92-109.

Condeelis J, Pollard JW. 2006. Macrophages: Obligate partners for tumor cell migration, invasion, and metastasis. Cell 124: 263-266.

Condeelis J, Segall JE. 2003. Intravital imaging of cell movement in tumours. Nat Rev Cancer 3: 921-930.

Coronella JA, Telleman P, Kingsbury GA, Truong TD, Hays S, Junghans RP. 2001. Evidence for an antigen-driven humoral immune response in medullary ductal breast cancer. Cancer Res 61: 7889-7899.

Coronella-Wood JA, Hersh EM. 2003. Naturally occurring B-cell responses to breast cancer. Cancer Immunol Immunother 52: 715-738.

Coukos G, Benencia F, Buckanovich RJ, Conejo-Garcia JR. 2005. The role of dendritic cell precursors in tumour vasculogenesis. Br J Cancer 92: 1182-1187.

Coussens LM, Raymond WW, Bergers G, Laig-Webster M, Behrendtsen O, Werb Z, Caughey GH, Hanahan D. 1999. Inflammatory mast cells up-regulate angiogenesis during squamous epithelial carcinogenesis. Genes Dev 13: $1382-1397$.

D’Cruz CM, Moody SE, Master SR, Hartman JL, Keiper EA, Imielinski MB, Cox JD, Wang JY, Ha SI, Keister BA, et al. 2002. Persistent parity-induced changes in growth factors, TGF- $\beta 3$, and differentiation in the rodent mammary gland. Mol Endocrinol 16: 2034-2051.

Dai X, Ryan GR, Hapel AJ, Dominguez MG, Russell RG, Kapp S, Sylvestre V, Stanley ER. 2002. Targeted disruption of the mouse CSF-1 receptor gene results in osteopetrosis, mononuclear phagocyte deficiency, increased primititive progenitor cell frequencies and reproductive defects. Blood 99: 111-120.

Daniel CW, Silberstein GB. 1987. Postnatal development of the rodent mammary gland. In The mammary gland, development, regulation, and function (ed. MC Neville, CW Danile), pp. 1-35. Plenum, New York.

De Palma M, Naldini L. 2006. Role of haematopoietic cells and endothelial progenitors in tumour angiogenesis. Biochim Biophys Acta 1766: 159-166.

De Palma M, Venneri MA, Galli R, Sergi Sergi L, Politi LS, Sampaolesi M, Naldini L. 2005. Tie2 identifies a 
hematopoietic lineage of proangiogenic monocytes required for tumor vessel formation and a mesenchymal population of pericyte progenitors. Cancer Cell 8: 211-226.

de Visser KE, Eichten A, Coussens LM. 2006. Paradoxical roles of the immune system during cancer development. Nat Rev Cancer 6: 24-37.

DeNardo DG, Coussens LM. 2007. Inflammation and breast cancer. Balancing immune response: Crosstalk between adaptive and innate immune cells during breast cancer progression. Breast Cancer Res 9: 212.

DeNardo DG, Baretto JB, Andreu P, Vasquez L, Kolhatkar N, Tawfik D, Coussens LM. 2009. CD4+ T cells regulate pulmonary metastasis of mammary carcinomas by enhancing protumor properties of macrophages. Cancer Cell 16: 91-102.

Disis ML, Calenoff E, McLaughlin G, Murphy AE, Chen W, Groner B, Jeschke M, Lydon N, McGlynn E, Livingston RB, et al. 1994. Existent T-cell and antibody immunity to HER-2/neu protein in patients with breast cancer. Cancer Res 54: 16-20.

Djonov V, Andres AC, Ziemiecki A. 2001. Vascular remodelling during the normal and malignant life cycle of the mammary gland. Microsc Res Tech 52: 182-189.

Egeblad M, Werb Z. 2002. New functions for the matrix metalloproteinases in cancer progression. Nat Rev Cancer 2: $161-174$.

Ewan KB, Shyamala G, Ravani SA, Tang Y, Akhurst R, Wakefield L, Barcellos-Hoff MH. 2002. Latent transforming growth factor- $\beta$ activation in mammary gland: Regulation by ovarian hormones affects ductal and alveolar proliferation. Am J Pathol 160: 2081-2093.

Fernandez Madrid F. 2005. Autoantibodies in breast cancer sera: Candidate biomarkers and reporters of tumorigenesis. Cancer Lett 230: 187-198.

Finak G, Bertos N, Pepin F, Sadekova S, Souleimanova M, Zhao H, Chen H, Omeroglu G, Meterissian S, Omeroglu A, et al. 2008. Stromal gene expression predicts clinical outcome in breast cancer. Nat Med 14: 518-527.

Gallina G, Dolcetti L, Serafini P, De Santo C, Marigo I, Colombo MP, Basso G, Brombacher F, Borrello I, Zanovello $P$, et al. 2006. Tumors induce a subset of inflammatory monocytes with immunosuppressive activity on CD8+ T cells. J Clin Invest 116: 2777-2790.

Gingras D, Renaud A, Mousseau N, Beliveau R. 2000. Shark cartilage extracts as antiangiogenic agents: Smart drinks or bitter pills? Cancer Metastasis Rev 19: 83-86.

Gocheva V, Wang HW, Gadea BB, Shree T, Hunter KE, Garfall AL, Berman T, Joyce A. 2010. IL-4 induces cathepsin protease activity in tumor-associated macrophages to promote cancer growth and invasion. Genes Dev 24: 241-255.

Gooch JL, Christy B, Yee D. 2002. STAT6 mediates interleukin-4 growth inhibition in human breast cancer cells. Neoplasia 4: 324-331.

Goswami S, Sahai E, Wyckoff JB, Cammer M, Cox D, Pixley FJ, Stanley ER, Segall JE, Condeelis JS. 2005. Macrophages promote the invasion of breast carcinoma cells via a colony-stimulating factor- $1 /$ epidermal growth factor paracrine loop. Cancer Res 65: 5278-5283.
Gouon-Evans V, Lin EY, Pollard JW. 2002. Requirement of macrophages and eosinophils and their cytokines/chemokines for mammary gland development. Breast Cancer Res 4: 155-164.

Gouon-Evans V, Rothenberg ME, Pollard JW. 2000. Postnatal mammary gland development requires macrophages and eosinophils. Development 127: 2269-2282.

Guy CT, Cardiff RD, Muller WJ. 1992. Induction of mammary tumors by expression of polyomavirus middle $\mathrm{T}$ oncogene: A transgenic mouse model for metastatic disease. Mol Cell Biol 12: 954-961.

Gyorki DE, Asselin-Labat ML, van Rooijen N, Lindeman GJ, Visvader JE. 2009. Resident macrophages influence stem cell activity in the mammary gland. Breast Cancer Res 11: R62.

Hagemann T, Wilson J, Kulbe H, Li NF, Leinster DA, Charles K, Klemm F, Pukrop T, Binder C, Balkwill FR. 2005. Macrophages induce invasiveness of epithelial cancer cells via NF-к B and JNK. J Immunol 175: 1197-1205.

Hanahan D, Weinberg RA. 2000. The hallmarks of cancer. Cell 100: 57-70.

Hinck L, Silberstein GB. 2005. Key stages in mammary development. The mammary end bud as a motile organ. Breast Cancer Res 7: 245-251.

Howard BA, Gusterson BA. 2000. Human breast development. J Mammary Gland Biol Neoplasia 5: 119-137.

Humphreys R. 1999. Programmed cell death in the terminal endbud. J Mamm Gland Biol Neoplasia 4: 213-220.

Humphreys RC, Krajewska M, Krnacik S, Jaeger R, Weiher H, Krajewski S, Reed JC, Rosen JM. 1996. Apoptosis in the terminal endbud of the murine mammary gland: A mechanism of ductal morphogenesis. Development 122: 4013-4022.

Ingman WV, Wyckoff J, Gouon-Evans V, Condeelis J, Pollard JW. 2006. Macrophages promote collagen fibrillogenesis around terminal end buds of the developing mammary gland. Dev Dyn 235: 3222-3229.

Khaled WT, Read EK, Nicholson SE, Baxter FO, Brennan AJ, Came PJ, Sprigg N, McKenzie AN, Watson CJ. 2007. The IL-4/IL-13/Stat6 signalling pathway promotes luminal mammary epithelial cell development. Development 134: 2739-2750.

King BL, Crisi GM, Tsai SC, Haffty BG, Phillips RF, Rimm DL. 2002. Immunocytochemical analysis of breast cells obtained by ductal lavage. Cancer 96: 244-249.

Kisucka J, Butterfield CE, Duda DG, Eichenberger SC, Saffaripour S, Ware J, Ruggeri ZM, Jain RK, Folkman J, Wagner DD. 2006. Platelets and platelet adhesion support angiogenesis while preventing excessive hemorrhage. Proc Natl Acad Sci 103: 855-860.

Kohrt HE, Nouri N, Nowels K, Johnson D, Holmes S, Lee PP. 2005. Profile of immune cells in axillary lymph nodes predicts disease-free survival in breast cancer. PLoS Med 2: e284.

Landskroner-Eiger S, Park J, Israel D, Pollard JW, Scherer PE. 2010. Morphogenesis of the developing mammary gland: Stage-dependent impact of adipocytes. Dev Biol 344: 968-978.

Lee TH, Seng S, Sekine M, Hinton C, Fu Y, Avraham HK, Avraham S. 2007. Vascular endothelial growth factor mediates intracrine survival in human breast carcinoma 
L.M. Coussens and J.W. Pollard

cells through internally expressed VEGFR1/FLT1. PLoS Med 4: e186.

Lee YT, Sheikh KM, Quismorio FP Jr, Friou GJ. 1985. Circulating anti-tumor and autoantibodies in breast carcinoma: Relationship to stage and prognosis. Breast Cancer Res Treat 6: 57-65.

Leek RD, Harris AL. 2002. Tumor-associated macrophages in breast cancer. J Mammary Gland Biol Neoplasia 7: $177-189$.

Leek RD, Hunt NC, Landers RJ, Lewis CE, Royds JA, Harris AL. 2000. Macrophage infiltration is associated with VEGF and EGFR expression in breast cancer. $J$ Pathol 190: $430-436$

Lewis C, Murdoch C. 2005. Macrophage responses to hypoxia: Implications for tumor progression and anti-cancer therapies. Am J Pathol 167: 627-635.

Lewis CE, Pollard JW. 2006. Distinct role of macrophages in different tumor microenvironments. Cancer Res 66: 605-612.

Lilla JN, Werb Z. 2010. Mast cells contribute to the stromal microenvironment in mammary gland branching morphogenesis. Dev Biol 337: 124-133.

Lin EY, Pollard JW. 2004. Macrophages: Modulators of breast cancer progression. Novartis Found Symp 256: 158-168; discussion 168-172, 259-269.

Lin EY, Pollard JW. 2007. Tumor-associated macrophages press the angiogenic switch in breast cancer. Cancer Res 67: 5064-5066.

Lin EY, Li JF, Gnatovskiy L, Deng Y, Zhu L, Grzesik DA, Qian H, Xue XN, Pollard JW. 2006. Macrophages regulate the angiogenic switch in a mouse model of breast cancer. Cancer Res 66: 11238-11246.

Lin EY, Nguyen AV, Russell RG, Pollard JW. 2001. Colony-stimulating factor 1 promotes progression of mammary tumors to malignancy. J Exp Med 193: 727-740.

Marshall KM, Hurley WL, Shanks RD, Wheeler MB. 2006. Effects of suckling intensity on milk yield and piglet growth from lactation-enhanced gilts. J Anim Sci 84: 2346-2351.

McDaniel SM, Rumer KK, Biroc SL, Metz RP, Singh M, Porter W, Schedin P. 2006. Remodeling of the mammary microenvironment after lactation promotes breast tumor cell metastasis. Am J Pathol 168: 608-620.

Monks J, Henson PM. 2009. Differentiation of the mammary epithelial cell during involution: Implications for breast cancer. J Mammary Gland Biol Neoplasia 14: 159-170.

Monks J, Geske FJ, Lehman L, Fadok VA. 2002. Do inflammatory cells participate in mammary gland involution? J Mammary Gland Biol Neoplasia 7: 163-176.

Mor G, Yue W, Santen RJ, Gutierrez L, Eliza M, Berstein LM, Harada N, Wang J, Lysiak J, Diano S, et al. 1998. Macrophages, estrogen and the microenvironment of breast cancer. J Steroid Biochem Mol Biol 67: 403-411.

Murdoch C, Giannoudis A, Lewis CE. 2004. Mechanisms regulating the recruitment of macrophages into hypoxic areas of tumors and other ischemic tissues. Blood 104: 2224-2234.

Nagai S, Toi M. 2000. Interleukin-4 and breast cancer. Breast Cancer 7: 181-186.
Neville MC, McFadden TB, Forsyth I. 2002. Hormonal regulation of mammary differentiation and milk secretion. $J$ Mammary Gland Biol Neoplasia 7: 49-66.

Neville MC, Medina D, Monks J, Hovey RC. 1998. The mammary fat pad. J Mammary Gland Biol Neoplasia 3: 109-116.

Nguyen AV, Pollard JW. 2000. Transforming growth factor $\beta 3$ induces cell death during the first stage of mammary gland involution. Development 127: 3107-3118.

Nozawa H, Chiu, Hanahan D. 2006. Infiltrating neutrophils mediate the initial angiogenic switch in a mouse model of multistage carcinogenesis. Proc Natl Acad Sci 103: 12493-12498.

O’Brien J, Schedin P. 2009. Macrophages in breast cancer: Do involution macrophages account for the poor prognosis of pregnancy-associated breast cancer? J Mammary Gland Biol Neoplasia 14: 145-157.

O’Brien J, Lyons T, Monks J, Lucia MS, Wilson RS, Hines L, Man YG, Borges V, Schedin P. 2010. Alternatively activated macrophages and collagen remodeling characterize the postpartum involuting mammary gland across species. Am J Pathol 176: 1241-1255.

Ojalvo LS, King W, Cox D, Pollard JW. 2009. High-density gene expression analysis of tumor-associated macrophages from mouse mammary tumors. Am J Pathol 174: $1048-1064$.

Ojalvo LS, Whittaker CA, Condeelis JS, Pollard JW. 2010. Gene expression analysis of macrophages that facilitate tumor invasion supports a role for Wnt-signaling in mediating their activity in primary mammary tumors. $J$ Immunol 184: 702-712.

Okamoto R, Ueno M, Yamada Y, Takahashi N, Sano H, Suda T, Takakura N. 2005. Hematopoietic cells regulate the angiogenic switch during tumorigenesis. Blood 105: 2757-2763.

Paape M, Mehrzad J, Zhao X, Detilleux J, Burvenich C. 2002. Defense of the bovine mammary gland by polymorphonuclear neutrophil leukocytes. J Mammary Gland Biol Neoplasia 7: 109-121.

Philippar U, Roussos ET, Oser M, Yamaguchi H, Kim HD, Giampieri S, Wang Y, Goswami S, Wyckoff JB, Lauffenburger DA, et al. 2008. A Mena invasion isoform potentiates EGF-induced carcinoma cell invasion and metastasis. Dev Cell 15: 813-828.

Pollard JW. 2004. Tumour-educated macrophages promote tumour progression and metastasis. Nat Rev Cancer 4: 71-78.

Pollard JW. 2009. Trophic macrophages in development and disease. Nat Rev Immunol 9: 259-270.

Pollard JW, Hennighausen L. 1994. Colony stimulating factor 1 is required for mammary gland development during pregnancy. Proc Natl Acad Sci 91: 9312-9316.

Pollard JW, Stanley ER. 1996. Pleiotropic roles for CSF-1 in development defined by the mouse mutation osteopetrotic (op). Adv Dev Biochem 4: 153-193.

Punt CJ, Barbuto JA, Zhang H, Grimes WJ, Hatch KD, Hersh EM. 1994. Anti-tumor antibody produced by human tumor-infiltrating and peripheral blood B lymphocytes. Cancer Immunol Immunother 38: 225-232.

Puxeddu I, Alian A, Piliponsky AM, Ribatti D, Panet A, LeviSchaffer F. 2005. Human peripheral blood eosinophils 
induce angiogenesis. Int J Biochem Cell Biol 37: 628636.

Qian BZ, Pollard JW. 2010. Macrophage diversity enhances tumor progression and metastasis. Cell 141: 39-51.

Richert MM, Schwertfeger KL, Ryder JW, Anderson SM. 2000. An atlas of mouse mammary gland development. J Mammary Gland Biol Neoplasia 5: 227-241.

Roth P. 1991. Colony-stimulating factor 1 levels in the human newborn infant. J Pediatr 119: 113-116.

Ryan GR, Dai XM, Dominguez MG, Tong W, Chuan F, Chisholm O, Russell RG, Pollard JW, Stanley ER. 2001. Rescue of the colony-stimulating factor 1 (CSF-1)-nullizygous mouse $\left(\mathrm{Csfl}^{\mathrm{op}} / \mathrm{Csf}^{\mathrm{op}}\right)$ phenotype with a CSF-1 transgene and identification of sites of local CSF-1 synthesis. Blood 98: 74-84.

Sakakura T. 1987. Mammary embryogenesis. In The Mammary gland: Development, regulation and function (ed. MC Neville, CW Danile), pp. 37-66. Plenum Press, New York.

Sangaletti S, Di Carlo E, Gariboldi S, Miotti S, Cappetti B, Parenza M, Rumio C, Brekken RA, Chiodoni C, Colombo MP. 2008. Macrophage-derived SPARC bridges tumor cell-extracellular matrix interactions toward metastasis Cancer Res 68: 9050-9059.

Santos SJ, Aupperlee MD, Xie J, Durairaj S, Miksicek R, Conrad SE, Leipprandt JR, Tan YS, Schwartz RC, Haslam SZ. 2009. Progesterone receptor A-regulated gene expression in mammary organoid cultures. J Steroid Biochem Mol Biol 115: 161-172.

Sapi E, Kacinski BM. 1999. The role of CSF-1 in normal and neoplastic breast physiology. Proc Soc Exp Biol Med 220: $1-8$.

Sapi E, Flick MB, Rodov S, Carter D, Kacinski BM. 1998. Expression of CSF-1 and CSF-1 receptor by normal lactating mammary epithelial cells. J Soc Gynecol Investig 5: $94-101$.

Sasmono RT, Oceandy D, Pollard JW, Tong W, Pavli P, Wainwright BJ, Ostrowski MC, Himes SR, Hume DA. 2003. A macrophage colony-stimulating factor receptor-green fluorescent protein transgene is expressed throughout the mononuclear phagocyte system of the mouse. Blood 101: $1155-1163$

Schedin P. 2006. Pregnancy-associated breast cancer and metastasis. Nat Rev Cancer 6: 281-291.

Scholl SM, Pallud C, Beuvon F, Hacene K, Stanley ER, Rohrschneider LR, Tang R, Pouillart P, Lidereau R. 1994. Anti-colony-stimulating factor- 1 antibody staining in primary breast adenocarcinomas correlates with marked inflammatory cell infiltrates and prognosis. $J$ Natl Cancer Inst 86: 120-126.

Schwertfeger KL, Rosen JM, Cohen DA. 2006a. Mammary gland macrophages: Pleiotropic functions in mammary development. J Mammary Gland Biol Neoplasia 11: 229-238.

Schwertfeger KL, Xian W, Kaplan AM, Burnet SH, Cohen DA, Rosen JM. 2006b. A critical role for the inflammatory response in a mouse model of preneoplastic progression. Cancer Res 66: 5676-5685.

Serafini P, Borrello I, Bronte V. 2006. Myeloid suppressor cells in cancer: Recruitment, phenotype, properties,
Leukocytes in Mammary Development and Cancer

and mechanisms of immune suppression. Semin Cancer Biol 16: 53-65.

Sferruzzi-Perri AN, Robertson SA, Dent LA. 2003. Interleukin-5 transgene expression and eosinophilia are associated with retarded mammary gland development in mice. Biol Reprod 69: 224-233.

Shackleton M, Vaillant F, Simpson KJ, Stingl J, Smyth GK, Asselin-Labat ML, Wu L, Lindeman GJ, Visvader JE. 2006. Generation of a functional mammary gland from a single stem cell. Nature 439: $84-88$.

Sheikh KM, Quismorio FP, Friou GJ, Lee YT. 1979. Ductular carcinoma of the breast: Serum antibodies to tumorassociated antigens. Cancer 44: 2083-2089.

Shimokawara I, Imamura M, Yamanaka N, Ishii Y, Kikuchi K. 1982. Identification of lymphocyte subpopulations in human breast cancer tissue and its significance: an immunoperoxidase study with anti-human $\mathrm{T}$ - and B-cell sera. Cancer 49: 1456-1464.

Soucek L, Lawlor ER, Soto D, Shchors K, Swigart LB, Evan GI. 2007. Mast cells are required for angiogenesis and macroscopic expansion of Myc-induced pancreatic islet tumors. Nat Med 13: 1211-1218.

Stein T, Morris JS, Davies CR, Weber-Hall SJ, Duffy MA, Heath VJ, Bell AK, Ferrier RK, Sandilands GP, Gusterson BA. 2004. Involution of the mouse mammary gland is associated with an immune cascade and an acute-phase response, involving LBP, CD14 and STAT3. Breast Cancer Res 6: R75-R91.

Stockmann C, Doedens A, Weidemann A, Zhang N, Takeda N, Greenberg JI, Cheresh DA, Johnson RS. 2008. Deletion of vascular endothelial growth factor in myeloid cells accelerates tumorigenesis. Nature 456: 814-818.

Stover DG, Bierie B, Moses HL. 2007. A delicate balance: TGF- $\beta$ and the tumor microenvironment. J Cell Biochem 101: $851-861$.

Szewczyk G, Szukiewicz D, Zaczek R, Maslinska D. 2000. Mast cells in the mouse mammary gland-correlation with the development of lactiferous structures. Folia Biol (Krakow) 48: 13-17.

Takakura N. 2006. Role of hematopoietic lineage cells as accessory components in blood vessel formation. Cancer Sci 97: 568-574.

Takakura N, Watanabe T, Suenobu S, Yamada Y, Noda T, Ito Y, Satake M, Suda T. 2000. A role for hematopoietic stem cells in promoting angiogenesis. Cell 102: 199-209.

Tan EM, Shi FD. 2003. Relative paradigms between autoantibodies in lupus and autoantibodies in cancer. Clin Exp Immunol 134: 169-177.

Tatarczuch L, Bischof RJ, Philip CJ, Lee CS. 2002. Phagocytic capacity of leucocytes in sheep mammary secretions following weaning. J Anat 201: 351-361.

Tatarczuch L, Philip C, Bischof R, Lee CS. 2000. Leucocyte phenotypes in involuting and fully involuted mammary glandular tissues and secretions of sheep. J Anat 196: 313-326.

Todaro M, Lombardo Y, Francipane MG, Alea MP, Cammareri P, Iovino F, Di Stefano AB, Di Bernardo C, Agrusa A, Condorelli G, et al. 2008. Apoptosis resistance in epithelial tumors is mediated by tumor-cell-derived interleukin-4. Cell Death Differ 15: 762-772. 


\section{L.M. Coussens and J.W. Pollard}

Toi M, Bicknell R, Harris AL. 1992. Inhibition of colon and breast carcinoma cell growth by interleukin-4. Cancer Res 52: $275-279$.

Tomer Y, Sherer Y, Shoenfeld Y. 1998. Autoantibodies, autoimmunity and cancer. Oncol Rep 5: 753-761.

Urdiales-Viedma M, Nogales-Fernandez F, Martos-Padilla S, Sanchez-Cantalejo E. 1986. Correlation of histologic grade and lymph node status with some histopathologic discriminants in breast cancer. Tumori 72: 43-51.

Van Nguyen A, Pollard JW. 2002. Colony stimulating factor- 1 is required to recruit macrophages into the mammary gland to facilitate mammary ductal outgrowth. Dev Biol 247: 11-25.

Wang W, Wyckoff JB, Goswami S, Wang Y, Sidani M, Segall JE, Condeelis JS. 2007. Coordinated regulation of pathways for enhanced cell motility and chemotaxis is conserved in rat and mouse mammary tumors. Cancer Res 67: 3505-3511.

Watson CJ. 2009. Immune cell regulators in mouse mammary development and involution. J Anim Sci 87: 35-42.

Webster JA, Beck AH, Sharma M, Esphinosa IBW, Schreuder M, Montgomery KD, Jensen KC, van de Rijn M, West R. 2010. Variations in stromal signature in breast and colorectal cancer metastases. J Pathol 222: 158-165.

Wernicke M. 1975. Quantitative morphologic assessment of immunoreactivity in regional lymph nodes of patients with carcinoma of the breast. Surg Gynecol Obstet 140: 919-924.

Wheeler TT, Broadhurst MK, Rajan GH, Wilkins RJ. 1997a. Differences in the abundance of nuclear proteins in the bovine mammary gland throughout the lactation and gestation cycles. J Dairy Sci 80: 2011-2019.
Wheeler TT, Kuys YM, Broadhurst MM, Molenaar AJ. 1997b. Mammary Stat5 abundance and activity are not altered with lactation state in cows. Mol Cell Endocrinol 133: $141-149$.

Wyckoff JB, Segall JE, Condeelis JS. 2000. The collection of the motile population of cells from a living tumor. Cancer Res 60: 5401-5404.

Wyckoff JB, Wang Y, Lin EY, Li JF, Goswami S, Stanley ER, Segall JE, Pollard JW, Condeelis J. 2007. Direct visualization of macrophage-assisted tumor cell intravasation in mammary tumors. Cancer Res 67: 2649-2656.

Wyckoff J, Wang W, Lin EY, Wang Y, Pixley F, Stanley ER, Graf T, Pollard JW, Segall J, Condeelis J. 2004. A paracrine loop between tumor cells and macrophages is required for tumor cell migration in mammary tumors. Cancer Res 64: 7022-7029.

Yang L, Debusk LM, Fukuda K, Fingleton B, Green-Jarvis B Shyr Y, Matrisian LM, Carbone DP, Lin PC. 2004. Expansion of myeloid immune suppressor $\mathrm{Gr}+\mathrm{CD} 11 \mathrm{~b}+$ cells in tumor-bearing host directly promotes tumor angiogenesis. Cancer Cell 6: 409-421.

Yang L, Huang J, Ren X, Gorska AE, Chytil A, Aakre M, Carbone DP, Matrisian LM, Richmond A, Lin PC, et al. 2008. Abrogation of TGF $\beta$ signaling in mammary carcinomas recruits $\mathrm{Gr}-1+\mathrm{CD} 11 \mathrm{~b}+$ myeloid cells that promote metastasis. Cancer Cell 13: 23-35.

Zinkernagel AS, Johnson RS, Nizet V. 2007. Hypoxia inducible factor (HIF) function in innate immunity and infection. J Mol Med 85: 1339-1346.

Zou W. 2005. Immunosuppressive networks in the tumour environment and their therapeutic relevance. Nat Rev Cancer 5: 263-274. 


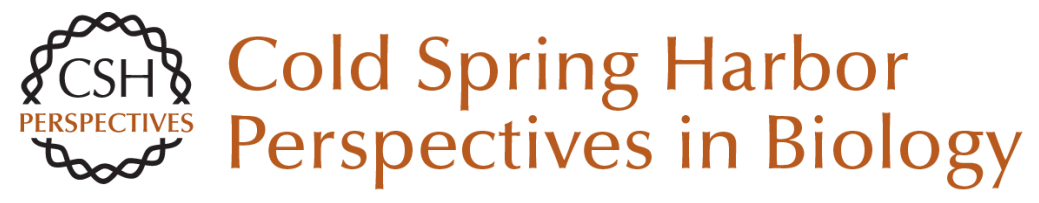

\section{Leukocytes in Mammary Development and Cancer}

Lisa M. Coussens and Jeffrey W. Pollard

Cold Spring Harb Perspect Biol 2011; doi: 10.1101/cshperspect.a003285 originally published online December 1, 2010

Subject Collection The Mammary Gland as an Experimental Model

On the Role of the Microenvironment in Mammary Gland Development and Cancer Derek Radisky

On Using Functional Genetics to Understand Breast Cancer Biology Kornelia Polyak

On Oncogenes and Tumor Suppressor Genes in the Mammary Gland Rushika M. Perera and Nabeel Bardeesy

On Leukocytes in Mammary Development and Cancer Cyrus M. Ghajar

On Chromatin Remodeling in Mammary Gland Differentiation and Breast Tumorigenesis Kornelia Polyak

On Hormone Action in the Mammary Gland J.M. Rosen

TGF- $\beta$ Biology in Mammary Development and Breast Cancer

Harold Moses and Mary Helen Barcellos-Hoff

A Compendium of the Mouse Mammary Tumor Biologist: From the Initial Observations in the House Mouse to the Development of Genetically Engineered Mice Robert D. Cardiff and Nicholas Kenney
On How Mammary Gland Reprogramming

Metalloproteinases Couple Form with Function Bonnie F. Sloane

On Molecular Mechanisms Guiding Embryonic

Mammary Gland Development Gertraud W. Robinson

On Stem Cells in the Human Breast Mark A. LaBarge

On Murine Mammary Epithelial Stem Cells:

Discovery, Function, and Current Status Jeffrey M. Rosen

On In Vivo Imaging in Cancer David Piwnica-Worms

Choosing a Mouse Model: Experimental Biology in Context--The Utility and Limitations of Mouse Models of Breast Cancer Alexander D. Borowsky

Mammary Gland ECM Remodeling, Stiffness, and Mechanosignaling in Normal Development and Tumor Progression Pepper Schedin and Patricia J. Keely

Molecular Mechanisms Guiding Embryonic Mammary Gland Development Pamela Cowin and John Wysolmerski

For additional articles in this collection, see http://cshperspectives.cshlp.org/cgi/collection/

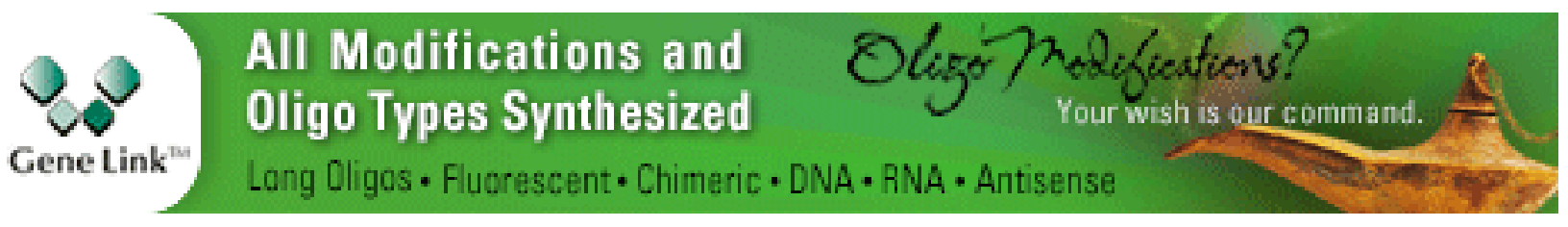


For additional articles in this collection, see http://cshperspectives.cshlp.org/cgi/collection/

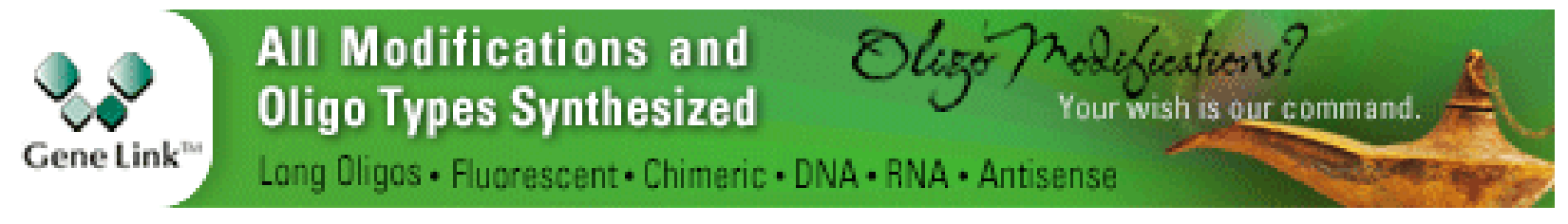

Copyright @ 2011 Cold Spring Harbor Laboratory Press; all rights reserved 